\title{
Askeladden Delta Sequence (Palaeocene) on Spitsbergen - sedimentation and controls on delta formation
}

\section{ARVID NØTTVEDT}

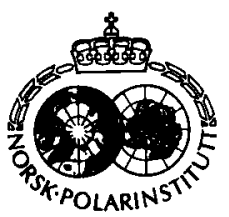

\begin{abstract}
Nøttvedt, A. 1985: Askeladden Delta Sequence (Palaeocene) on Spitsbergen - sedimentation and controls on delta formation. Polar Research 3 n.s., 21-48.

Because of its coal potential the basal Tertiary Firkanten Formation on Spitsbergen has received much attention. The formation is an offset stacked (overall transgressive) sequence comprising at least eight coastal/deltaic units each of which has a regressive character and is 10 to $30 \mathrm{~m}$ thick. The lowermost coal-bearing unit (Todalen Member) represents deltas which were largely fluvial- and tide-dominated while the upper unit deltas (Endalen Member) were wave-dominated. One of the transitional deltaic units, the Askeladden Sequence, has been examined in some detail along depositional dip $(\sim 15 \mathrm{~km})$ and strike $(\sim 55 \mathrm{~km})$. This unit represents wave- (tide)dominated delta conditions, and two main facies associations are recognized:

1. Delta front/shoreline deposits (Facies Association I).

2. Delta plain/coastal plain deposits (Facies Association II).

Askeladden sequence accumulated in a shallow, low-gradient embayment (Nordenskiöld Land subbasin) open to the south and southwest. Periodic, strong longshore currents caused a net northwards transport of sediment. Tidal range is considered close to the micro/meso-tidal boundary, and estimates of ancient wave regime indicate overall moderate wave conditions, suggesting that the extensive wavereworking of the delta front/shoreline sands is related to relatively slow rates of fluvial input. Climate and tectonics are considered important contributory controls on sedimentation.
\end{abstract}

Arvid Nфttvedt, Norsk Hydro Research Centre, Lars Hillesgt. 30, N-5000 Bergen, Norway.

\section{Introduction}

\section{Central Tertiary basin}

Svalbard is located between 77 and $80^{\circ}$ north, in the northwestern corner of the otherwise submerged Barents shelf (Fig. 1). In the south-central parts of the main island Spitsbergen, a $5-6 \mathrm{~km}$ thick succession of post-Caledonian (Hecla Hoek) rocks is preserved in a broad syncline termed the Central Basin or Spitsbergen Trough (Fig. 1). The syncline developed from late Eocene-early Oligocene upthrusting and compressional deformation along the West Spitsbergen orogen (Harland 1973; Kellogg 1975).

The Tertiary strata of the Central Basin rest unconformably on Lower Cretaceous strata (Fig. 2), due to late Cretaceous epeirogenic uplift of northern Spitsbergen (Orvin 1934; Atkinson 1963). Although the basin edges are likely to have varied somewhat in position through time, the original basin margins have probably not extended very far beyond the present Central Basin margins (Steel et al. 1981), which are sub- parallel to the old Caledonian north-south structural alignment.

\section{Basal Tertiary succession}

The Central Basin formed on a 'sheared' continental margin in Palaeocene time, as Greenland moved laterally from the Barents Shelf. The basal Tertiary deposits (Heer 1876; Nathorst 1910; Ravn 1922; Orvin 1940; Atkinson 1963; Livshits 1974; Vonderbank 1970; Birkenmayer 1972; Major \& Nagy 1972; Kellogg 1975; Harland 1975; Harland et al. 1976; Manum \& Throndsen 1978a, b; Steel et al. 1979, 1981) are of considerable economic importance, with coal being worked both along the northeastern margin by Norwegians, and the northwestern margin by the Soviet Union. The coal-bearing Todalen Member (Kalgraff 1978) makes up the lower half of the 100 to $200 \mathrm{~m}$ thick Firkanten Formation (Fig. 2) (Flood et al. 1971; Major \& Nagy 1972), which comprises some 6 to 8 coastal-deltaic units, each 10 to $30 \mathrm{~m}$ thick (Kellogg 1975; Kalgraff 1978; 


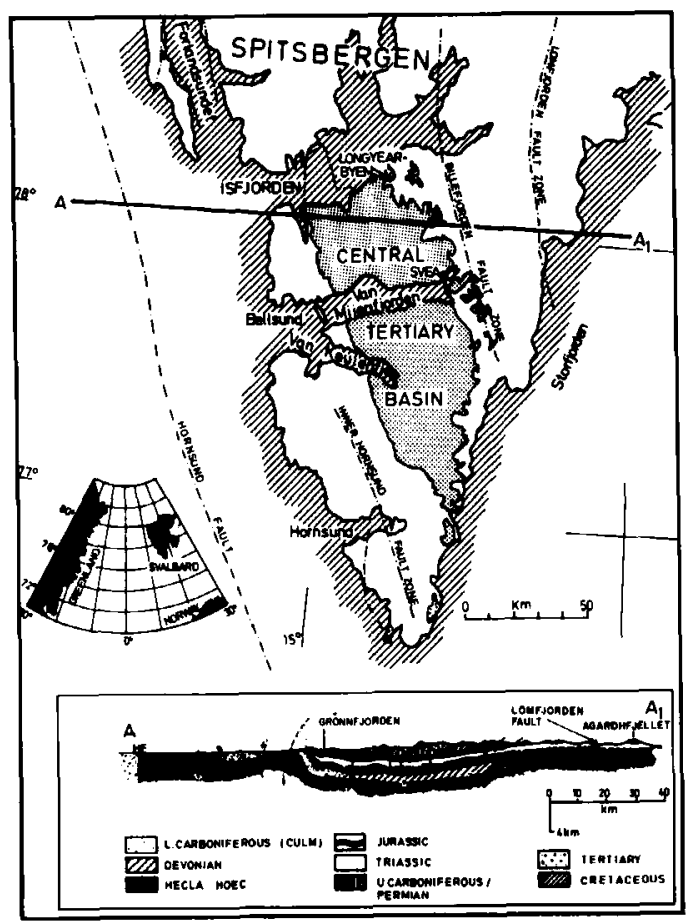

Fig. 1. Outline map and structural configuration of the Central Tertiary Basin on Spitsbergen.

Steel et al. 1979, 1981; Ytreland 1980; Tønseth 1981). The lowermost (Todalen Member) units are largely tide and fluvial dominated while the upper (Endalen Member) units are wave dominated, and the entire sequence is offset stacked, with an overall transgressive nature (Kellogg 1975; Steel et al. 1979, 1981) (Fig. 3).

\section{Age of deposits}

On the basis of plant fossils, the Tertiary succession on Spitsbergen was originally thought to be Miocene in age (Heer 1876; Nathorst 1910). Subsequent work (Ravn 1922) on some of the molluscan faunas yielded Palaeocene-Eocene ages, and Livshits (1965, 1974), who took into consideration plant fossils, molluscs, foraminifera and palynomorphs, suggested the succession to be Palaeocene-Oligocene, possibly Miocene, in age.

Despite some disagreement regarding the upper part of the succession, the age of the Firkanten Formation is generally held to be Palaeocene, and recent palaeontological and palynological studies indicate that it is no younger than early Palaeocene (Vonderbank 1970; Manum \& Throndsen 1978a). Manum \& Throndsen (1978a) further suggest a late Palaeocene age for the base of Gilsonryggen Formation, pushing the Palaeocene/Eocene boundary considerably higher than was done by Livshits (1974).

\section{Aim of study}

One of the transitional deltaic units, the Askeladden sequence (Fig. 2), has been studied in some detail, and is the subject of the present analysis. The study area is along the northeastern Central Basin margin between Longyearbyen and Svea (Fig. 4). The exposures are numerous, and almost 100 sections have been measured, mostly in the Adventdalen region.

The present study concentrates on a detailed facies analysis, with emphasis on facies sequences and facies distribution. It was carried out in order to reconstruct the regime and morphology of the Askeladden depositional system. At the same time an attempt is made to evaluate the extent to which the Askeladden delta characteristics depend on source area and receiving basin characteristics, as well as climatic and tectonic settings. A detailed interpretation of the Askeladden sequence may also provide a model for the understanding of the entire Firkanten Formation sedimentation.

\section{Regional setting}

The Caledonian orogeny created a dominantly north-south oriented structural alignment on the Svalbard Platform, and this acted as an important control on later tectonic activity. Hence, postCaledonian tectonism caused repeated fracturing and faulting along the north-south lineaments, such as the Billefjorden and Lomfjorden Fault Zones (Fig. 1) (Harland et al. 1974; Parker 1966).

An east-northeastwards facies change and rapid thinning of the Askeladden sequence (see Fig. 7) suggest that the eastern margin of the original basin did not extend very far beyond the present day Central Basin margin. Facies patterns and grain size parameters suggest a nearby source area. Hence it is speculatively suggested that the Billefjorden and/or Lomfjorden Fault Zones were active also in early Palaeocene times, bounding the basin to the east. A similar proposal has been 

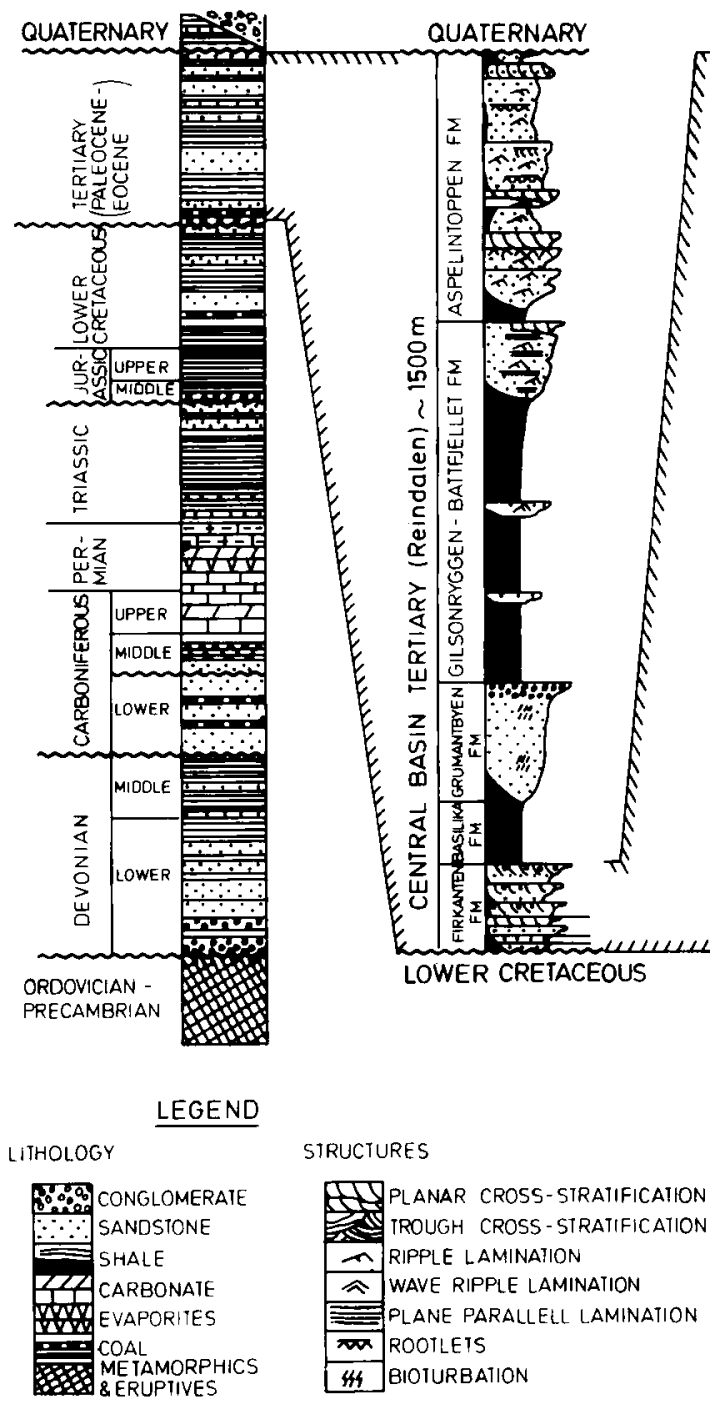

Fig. 2. The post lower Palaeozoic Central Basin succession, with emphasis on Tertiary lithostratigraphy and the position of the early Palaeocene Askeladden sequence.

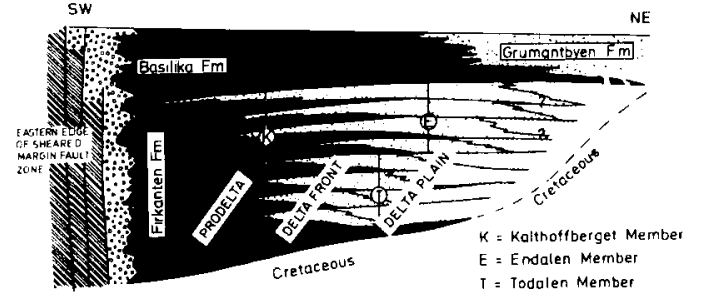

Fig. 3. Schematic diagram showing the repeated regressive increments in the overall transgressive Firkanten-Basilika Formations. Facies along western edge of basin are speculative (from Steel et al. 1981). put forward by Steel (pers. comm.), who has studied the overlying Endalen Member. A lack of coarse-grained sediments close to the Billefjorden Fault Zone in the Reindalen area, however, suggests that it was not this fault zone, but rather the Lomfjorden Fault Zone which bounded the eastern edge of the basin. An alternative possibility is that the Reindalen section of the Billefjorden Zone did not shed significant amounts of sediment.

Easterly oriented palaeocurrents in the basal Todalen Member conglomerates. in Grønfjorden 


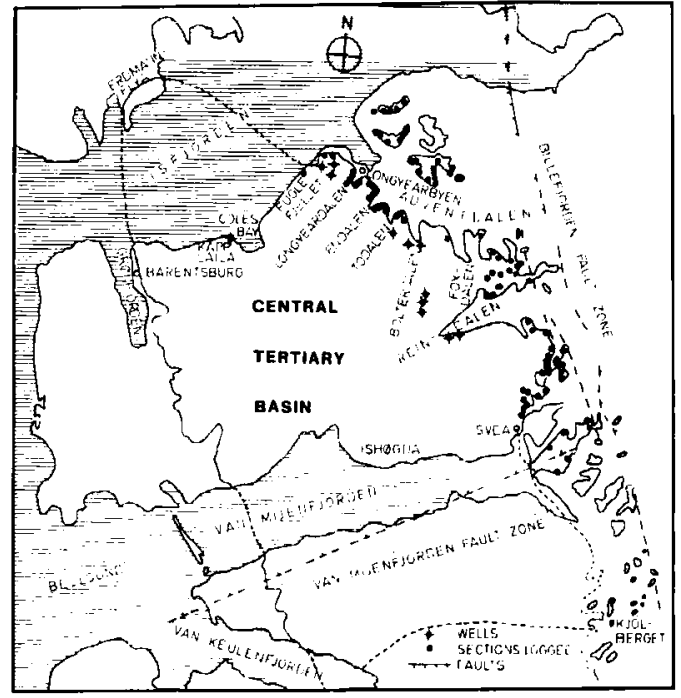

Fig. 4. Location map, and positions of measured sections and wells used in this study.

(Fig. 4) are interpreted in terms of a westnorthwesterly source area (Kalgraff 1978; Ytreland 1980), and it has been speculatively suggested that there was a high-standing fault block somewhat west of the present western margin of the Central Basin (Steel et al. 1981). Although there is no evidence of active faulting during deposition of the Askeladden sequence, the Askeladden equivalent in this area is characterized by coastal plain deposition (see Fig. 18), suggesting that the horst was still of topographic importance.

The concept of an active Billefjorden and/or Lomfjorden Fault Zone to the east and a highstanding horst to the west supports the notion that the Palaeocene Central Basin was faultbounded (Livshits 1974), i.e. a rift basin or half graben, some $60-90 \mathrm{~km}$ wide (Fig. 5). The formation of the trough is related to early Palaeocene transtensional movements along the Hornsund Fault Zone (Harland 1969, 1971; Lowell 1971; Kellogg 1975; Steel et al. 1981), prior to the separation of the Barents Shelf and North Greenland plates (Fig. 5). There is some evidence that this Palaeocene trough was not uniform along its length, however. Cross sections along both the eastern and western margins of the Central Basin indicate the presence of an east-west oriented fault zone immediately south of Van Mijenfjorden (Fig. 6). This fault zone was the northern boundary of a relatively high-standing, south-

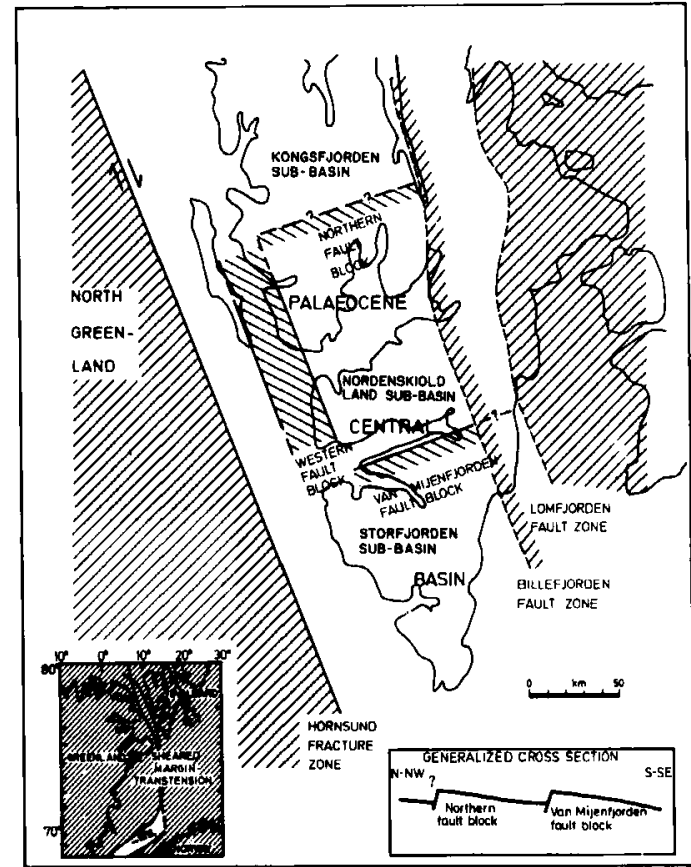

Fig. 5. Major tectonic elements of the early Palaeocene Central Basin as inferred from sedimentological studies.

wards tilted block. Such a structural pattern, where the graben floor was broken up into a series of tilted blocks, may be tentatively suggested also for the region north of Isfjorden (Fig. 5). The above tectonic pattern is known to occur associated with oblique fracturing (Surlyk 1978), and suggests that the Palaeocene Spitsbergen trough may have opened successively from the south towards the north. This again suggests that the Palaeocene Spitsbergen basins may in fact become progressively younger towards the north.

\section{The Askeladden Sequence - facies analysis}

The Askeladden sequence is defined as the strata lying above the Longyear coal seam and below the Endalen Member sandstones (Fig. 2). The sequence consists of a lower part (generally more than two thirds of the thickness) which shows a broad upwards coarsening from bioturbated and ripple-laminated sandstones to massive, horizontal or low angle stratified sandstones; and an upper part dominated by black shales, thin coals and ripple laminated sandstones. At some localities the upper part is dominated by coarse sand- 


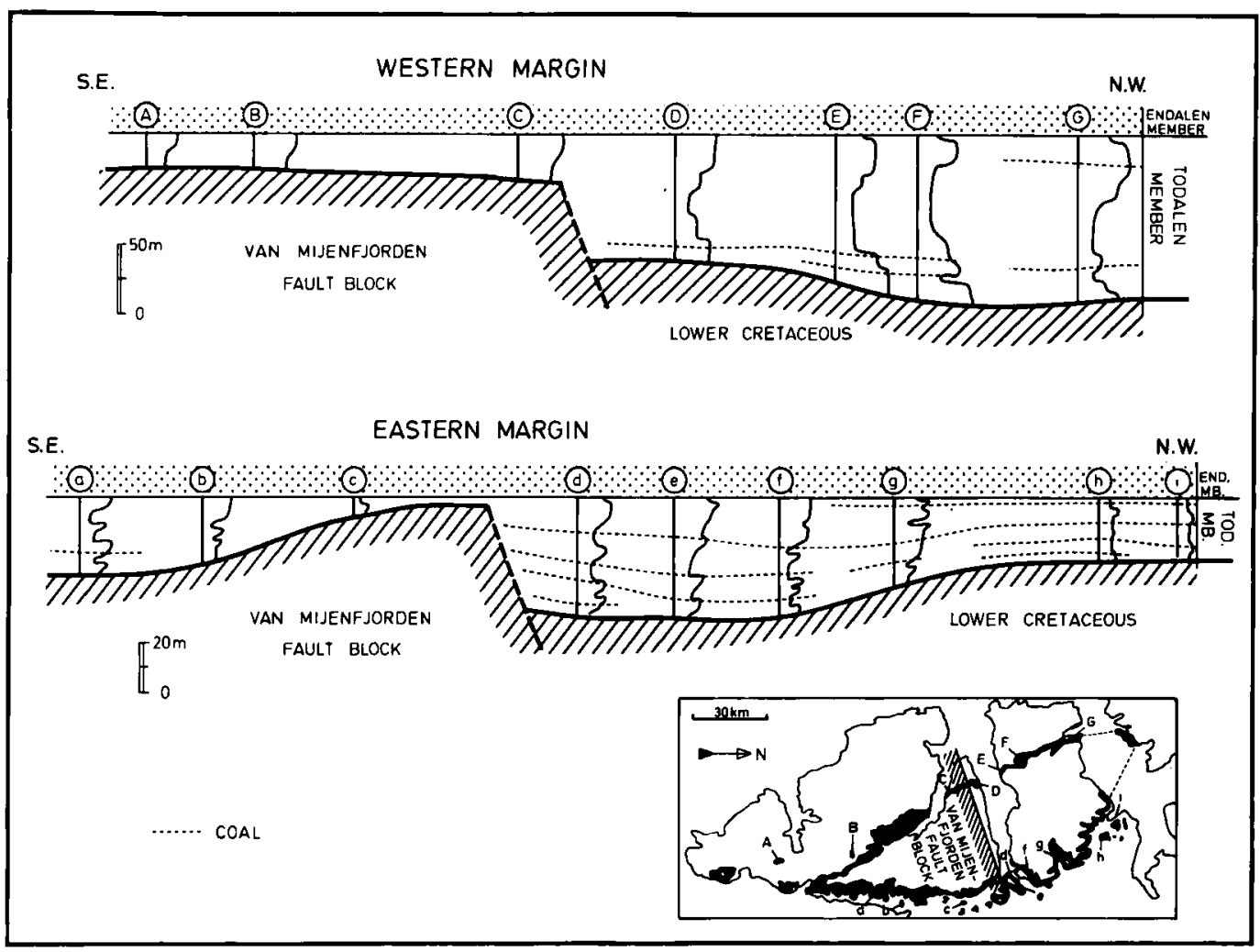

Fig. 6. Generalized cross sections of the Todalen Member along the eastern and western margin of the Central Tertiary Basin (modified from Steel et al. 1981), showing the onlap of coal-bearing strata against the inferred Van Mijenfjorden fault block.

stones or conglomeratic sandstones. The lower part of the sequence (Facies Association I) is interpreted as shoreline/delta front deposits while the upper part (Facies Association II) comprises delta plain deposits (Fig. 7).

The two facies associations clearly have an interfingering relationship in a northeast-southwest direction, the shoreline/delta front unit pinching out northeastwards (updip) into delta plain sediments, indicating that this was the direction of depositional dip (Fig. 7). In a northwest-southeast direction the two associations persist as discrete units, confirming that this direction represents the palaeostrike and that the palaeocoastline was oriented roughly parallel to the present northeastern margin of the Central Basin. The above large-scale facies configurations are the basis for further palaeocurrent interpretation below.

\section{Facies association I (shoreline delta front)}

Facies association I consists mostly of sandstones and sandy siltstones, with subordinate shales and silty shales. Grain size generally decreases slightly southwestwards (downdip), and the facies gradually take on a relatively 'distal' character. In the most basinward exposures/boreholes, where the Askeladden sequence is entirely of marine origin, there is an inferred maximum thickness of approximately $25-30 \mathrm{~m}$.

The sheet-like geometry of the association, bioturbation of marine affinities, abundant wave-generated sedimentary structures, and association with coal below and above, suggest that these sandstones were deposited in a nearshore marine environment which was subject to extensive wave winnowing and biological reworking. Whether this was a true delta front or clastic shoreline environment, or both, will be discussed later. The lithological elements that make up the facies association are:

Facies IA - interbedded fine sandstones and shales

Facies IB - fine sandstones with conglomerate lenses 


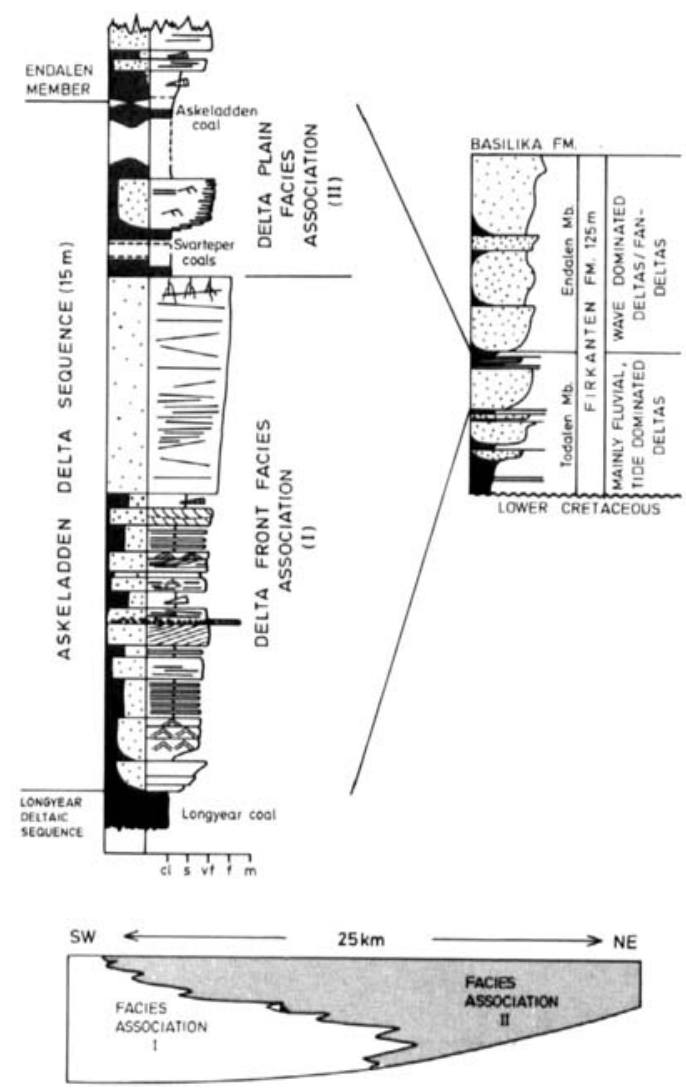

Fig. 7. Stratigraphic log of the Askeladden sequence (Endalen E.), and schematic cross section showing the vertical and lateral relationship between Facies Associations I and II.

Facies IA - Description and interpretation of processes

Facies IA consists of very fine to fine-grained, grey to light red standstones, frequently interbedded with sandy silts and shales. The vertical sequence is commonly (though not always) coarsening upwards, as defined by an increase in thickness of sandlayers, and by a slight increase in grain size (Fig. 8). The interbedded sand and mud layers are often laterally impersistent, giving the impression of lenticularity between cosets. The muds are usually very thinly bedded, with rare thin layers of ripple laminated sandstone preserved as lenticular bedding. The muddy interbeds indicate deposition mostly from suspension, with subordinate traction currents of minor strength.

Ripple lamination (mostly wave-generated), some planar and trough cross-stratification, plane parallel lamination, low-angle cross-lamination and hummocky cross-stratification characterize the $5-80 \mathrm{~cm}$ thick sandstone layers, which sometimes also appear massive. Individual beds are often topped by erosive sets of wave ripples, and thinner interbeds of mud are preserved as flaser bedding. The sandlayers are interpreted as deposited by waves and currents of varying strengths. Ripples, and planar/trough cross-beds (sand wave/dune migration) are clearly lower flow regime features. Plane parallel lamination and low-angle cross-lamination, on the other hand, represent upper flow regime conditions, and the lack of well-developed parting lineation on bedding surfaces may reflect high ratios of suspended/traction load transport. The origin of hummocky cross-stratification is not yet understood, but the implication of moderate to high wave energy conditions (Harms 1975b) still seems valid, whether or not superimposed on unidirectional currents (Harms et al. 1982). The scouring effect of the wave ripples is evidence of late stage reworking rather than of decelerating current conditions, suggesting that the currents were highly intermittent.

At a few localities, there is clear evidence of scouring within the upper part of this facies. These channelized features are less than $1 \mathrm{~m}$ in depth, and $10-15 \mathrm{~m}$ in width. The grain size is only slightly coarser than in the surrounding sediments, and the dominant sedimentary structures are planar and trough cross-strata, sometimes capped by small-scale, ripple lamination, and thin veneers of mud, suggestive of intermittent currents also here.

So far, no fossils have been observed in these sediments. However, locally the facies may be intensively disturbed by bioturbation, and several types of burrows have been recognized, among which the Ophiomorpha nodosa (dwelling structure) and Planolites, or possibly Chondrites? (feeding structures), are the most conspicuous types.

The organic content is moderate to low, with scattered coaly laminae or finely distributed coal particles in the muddy sediments. None of the coal laminae represent in situ coal development. Siderite, both as nodules and bands, is common in the more fine-grained parts.

Facies IA commonly overlies either the Longyear coal seam directly, or various types of delta plain sediments related to the Longyear delta sequence, and is, in turn, overlain by Facies IB (Fig. 8). Facies 1A increases in volume towards 


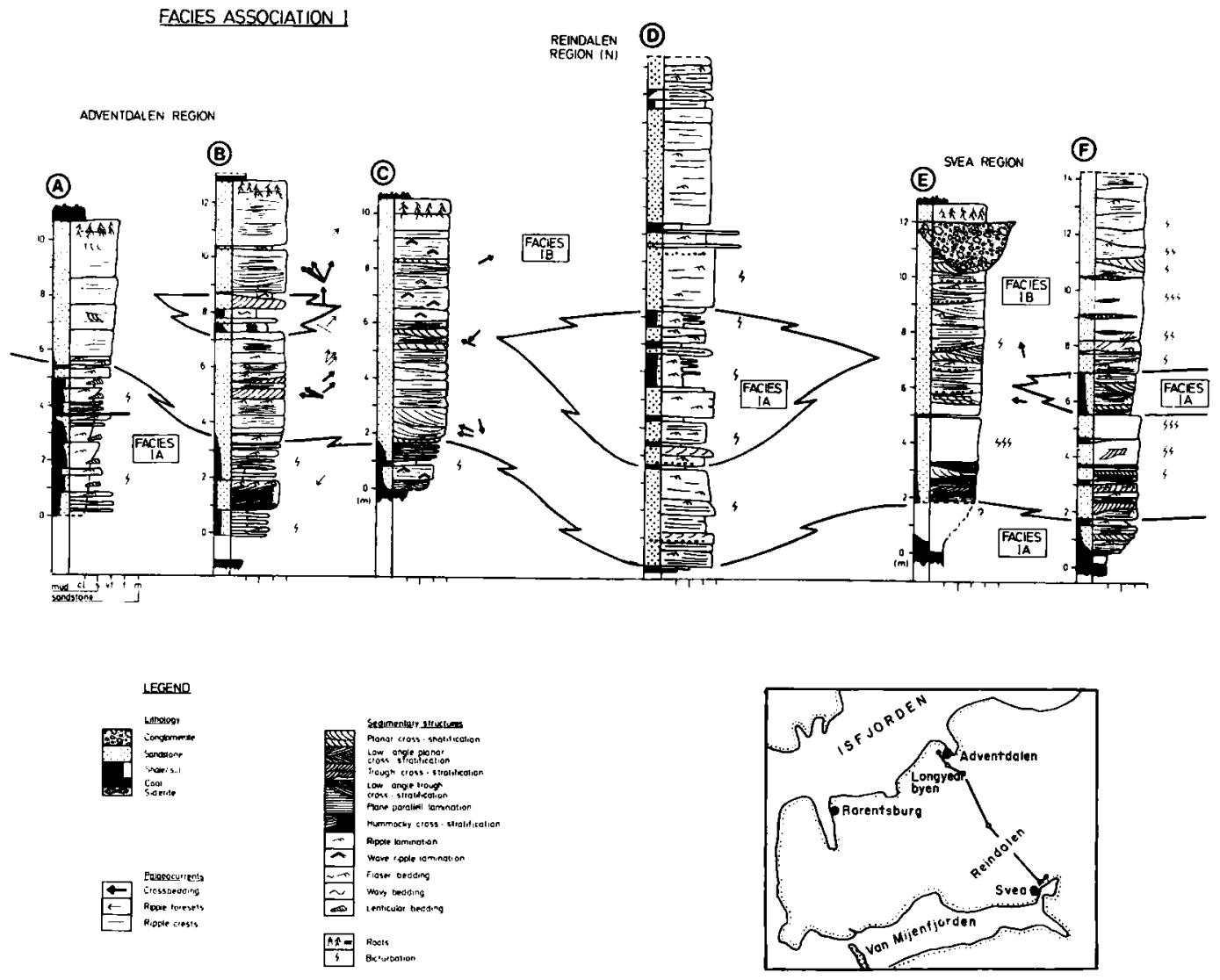

Fig. 8. Representative sections through Facies Association I. A - Todalen N. E., B - Longyeardalen N. W., C - Longyeardalen S. E., D - Endalen E., E - Platåberget N. (well), F- Deinbolltoppane S. E., G - Kolhamaren S. W., H - Fosstoppen S.

the southwest, which is downdip in relation to the palaeocoastline.

\section{Environmental interpretation}

General. - The interbedded sandstones and sandy mudstones of Facies IA show clear evidence of having been influenced by various processes. The frequent occurrence of intense bioturbation within this facies implies that biological agents sometimes dominated those tending to produce physical sedimentary structures. The sedimentary structures reflect varying energy types, but the rhythmic interbedding of sandstone and sandy mudstone, and the evidence of intermittent currents suggest that the depositional environment was characterized overall by the alternation of weaker and stronger energy levels. The above described features are typical of modern day upper offshore to lower shoreface zones, with high energy storm waves and storm induced bottom currents superimposed on low energy fairweather processes. The sandy mud interbeds, as well as the frequent ripple capping of individual beds, most likely represent fairweather deposition and reworking, while the large-scale crossbedded, plane parallel laminated and hummocky cross-stratified sandstone layers are probably mainly storm deposited. The shallow scours could be interpreted as rip channels (Komar \& Inman 1970) or, perhaps, as storm surge ebb channels (Hayes 1967; Banks 1973), since rip currents commonly occur higher up on the shoreface profile.

The Ophiomorpha burrow is produced in modern day environments by the shrimp Callianassa major (Weimer \& Hoyt 1964), while the small Planolites/Chondrites tubes are made by worms. Although diagnostic marine indicators, none of the observed burrows are facies diag- 
nostic. In the ancient record, they are related to both the intertidal (Skolithos assemblage) and subtidal (Cruziana assemblage) zones.

Wave characteristics. - Using the methods of Clifton (1976) and Komar (1976), the abundance of upper flow regime plane parallel lamination provides a means of estimating the character of the storm waves. Plane parallel lamination is found as much as $11 \mathrm{~m}$ below the topmost rooted horizon in units of Facies Association I (Fig. 8) and, assuming that later compaction has been negligible and that relative sea level was approximately constant, this distance will represent the water depth at the time of deposition. The orbital velocities required to form plane parallel lamination in very fine sand are in the order of 60$70 \mathrm{~cm} / \mathrm{sec}$ (Clifton 1976). At a depth of $11 \mathrm{~m}$, short period waves $(T \leqq 4 \mathrm{sec})$ would require wave heights of more than $7 \mathrm{~m}$ to produce these velocities, and such waves are too steep to exist. However, $6 \mathrm{sec}$ waves with wave heights $\mathrm{H}=2.4 \mathrm{~m}$, or $8-10 \mathrm{sec}$ waves with wave heights of the order of $1.7-1.8 \mathrm{~m}$, would readily induce orbital velocities of $70 \mathrm{~cm} / \mathrm{sec}$.

These calculations suggest that the average storm waves may have been characterized by intermediate wave periods, and moderate wave heights. As storm waves are commonly rather steep (Kumar \& Sanders 1976), T $=6 \mathrm{sec}$ and $\mathrm{H}=2.4 \mathrm{~m}$ would probably be most applicable.

Rooting several metres down in occasional Facies IB sequences (see p. 31), however, indicates some vertical stacking of facies, suggesting that relative see level was not constant. This means that the above calculations may not represent absolute values, but rather indicate maximum ancient wave conditions.

Palaeocurrents. - Two distinct modes of crossbedding are recognized within this facies. Small-scale ripple lamination, with foreset inclination directed mainly towards the southwest, and with a slight asymmetry towards west-northwest forms the first mode (Fig. 9). A secondary mode is formed by the various types of large-scale cross-bedding, trough and planar sets of crossstrata as well as hummocky cross-stratification. This group of palaeocurrent readings show a high degree of dispersion. A summary examination of the inclination direction, however, indicates a predominant dip towards north-northwest, slightly inclined towards the palaeocoastline.

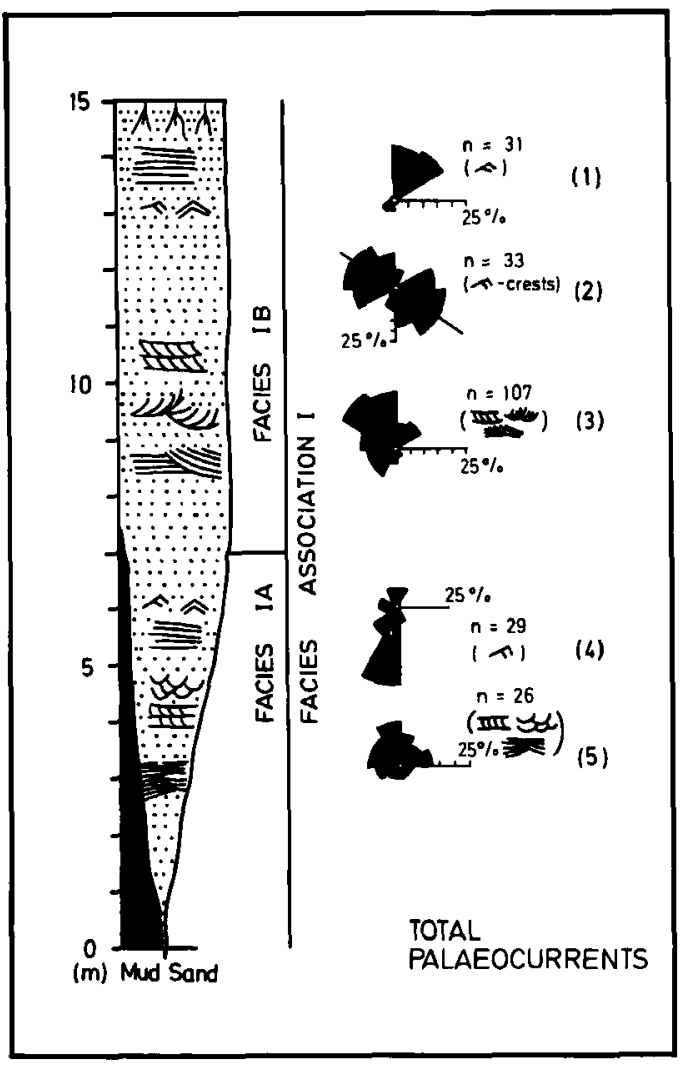

Fig. 9. Summary of the different modes of cross-bedding within Facies Association $I$ in the Adventdalen area.

Having established the marine nature of Facies IA, the dominantly seaward direction of smallscale cross-bedding and ripple lamination may be interpreted as resulting from shore normal currents related to the velocity asymmetry of wave motions (Clifton 1976; Davis 1978), tidal currents (De Raaf \& Boersma 1971), storm surge ebb currents (Hayes 1967), or possibly rip currents (Hunter et al. 1979). In general, seaward oriented shore normal currents are generated by the steeper waves (Davis 1978) commonly associated with the breaker zone (Clifton 1976). Rip currents are also generated within the surf/breaker zone, although they may extend for some distance seaward (Komar \& Inman 1970; Davis 1978). However, neither of these mechanisms is likely to produce time persistent unimodal currents in water depths of the order of $10 \mathrm{~m}$, regarded above as a reasonable approximation. Weak to moderate tidal currents, on the other hand, are capable of stirring up the seafloor at depths of several tens of metres, and in the case of strong 
ebb dominance they will produce an apparently unimodal, seaward oriented palaeocurrent pattern (Johnson 1978). The many evidences of tidal influence within the Todalen Member (Dalland pers. comm.; Steel et al. 1981, Facies IID below), support the proposition of prevalent ebb-dominated tidal currents, and also several factors within this particular facies may suggest some tidal contribution to wave processes. These are, on the basis of the work by De Raaf \& Boersma (1971):

1. Common coupling in super- or juxtaposition of sand- and interbedded sand/mud units.

2. Intricate alternation between coarsening upward and fining upward units.
3. Intermittent character of currents, also on a very small scale.

4. Widespread and quantitatively important development of beds of flaser and lenticular character.

5. Rapid lateral and vertical variations in burrowing intensity.

Another feasible explanation, however, is by storm surge ebb currents (Hayes 1967), which are thought to be an important mechanism for moving sand from the nearshore to the offshore environment (see also Banks 1973). The many indications of storm activity within Facies IA are coherent with such a model. The problem is why the large-scale structures which are thought to be

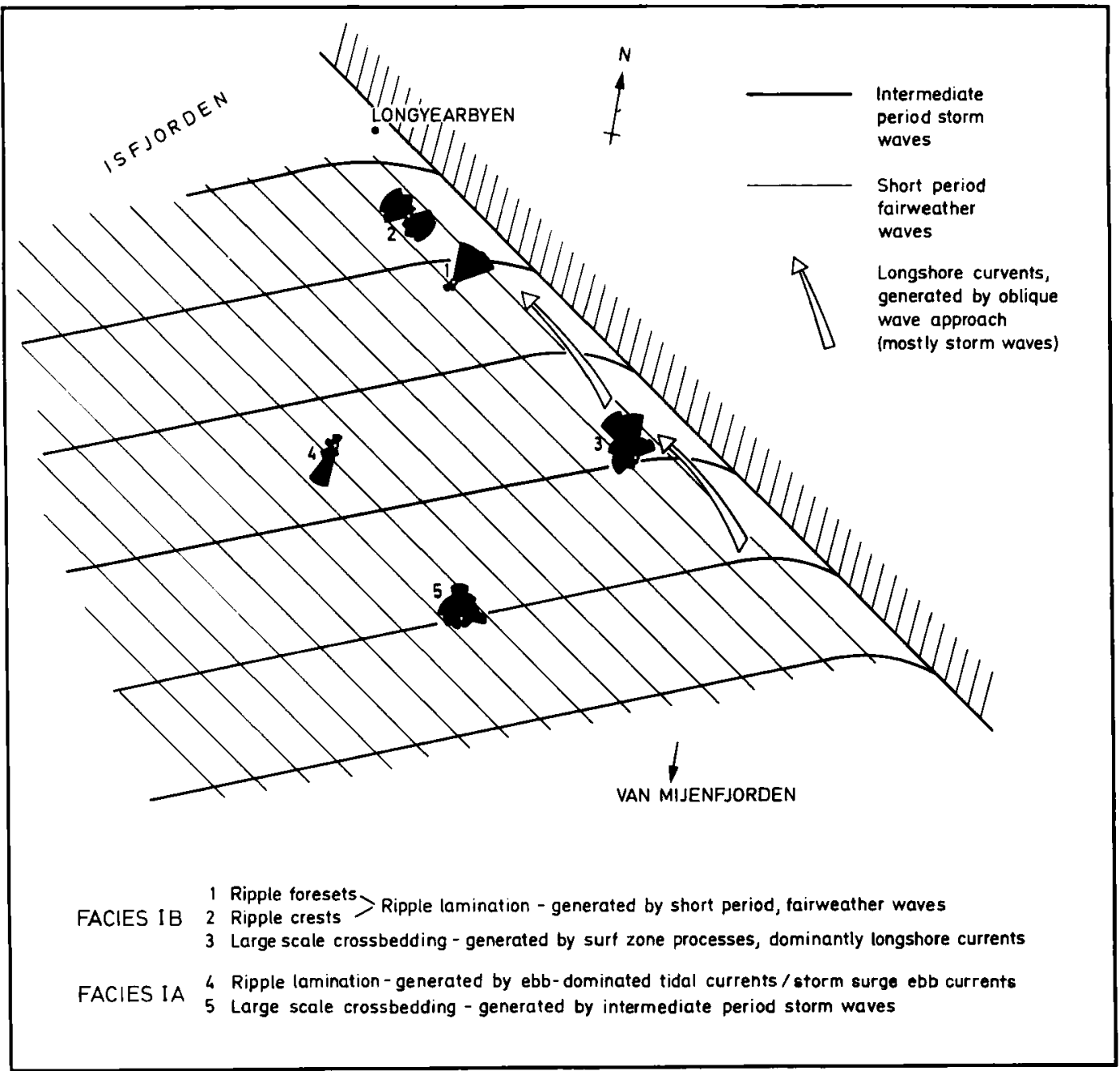

Fig. 10. Palaeohydraulic interpretation of the palaeocurrents summarized in Fig. 10. 
more typically storm generated show opposite directional properties.

Despite a relatively high degree of dispersal, the predominant north-northwesterly dip of the large-scale storm-produced structures indicates a main direction of storm wave propagation from south-southeast (Fig. 10), i.e. towards the direction of the open early Northeast Atlantic Sea.

\section{Facies IB - description and interpretation of} processes

The coarsening upward transition from Facies IA to Facies IB is commonly very gradual, and often clearly visible by a change in weathering colour from reddish to yellow.

Facies IB consists of white to light grey, sometimes dark grey, well-sorted, fine-grained sandstones, with infrequent thin interbeds/lenses of conglomerate (Fig. 8). It is characterized by plane parallel lamination, ripple lamination, large-scale trough and planar cross-stratification, and subordinate large, low-angle trough cross-beds (Fig. 11). Some of these low-angle troughs are clearly large scours, which appear to have been draped by the infilling sediment, and gradually passing upwards into plane parallel lamination in a manner comparable to hummocky cross-strata. Due to poorly developed slip faces, palaeoflow directions are very often difficult to obtain. The cosets sometimes appear entirely massive, probably because of the good sorting and intense silicification of these rocks.

An upward transition from ripple lamination, trough and planar cross-strata, and subordinate plane parallel lamination, to dominantly plane parallel lamination, frequently with parting lineation on bedding surfaces, and rare sets of planar, low-angle planar and trough cross-stratification, is commonly observed. Straight crested wave ripples, often symmetrical, on top of individual sets, and thin mud-layers $(<2 \mathrm{~cm})$ between cosets are commonly developed in the lower half of this facies, but become decreasingly important upwards. Also of note is the lamination typically becoming less distinct upwards. Set thickness varies between 5 and $90 \mathrm{~cm}$, and average thickness of cosets is in the order of $30-50 \mathrm{~cm}$; usually they become thicker upwards.

Although commonly subparallel, some of the cosets, especially in the lower part, may be slightly dipping. Insufficient exposure makes it difficult to follow individual cosets for any distance, but some are clearly seen to pinch out upwards. No preferred orientation of dip has been obtained. In the lowermost part of the sequence, dipping cosets can sometimes be traced down into the interbedded sands and muds of Facies IA. These cosets typically become more and more thinly bedded downwards, and some can be seen to pass into homogeneous shale layers. Characteristic of these layers is a downward steepening of internal bedding. The features described above are often associated with an intermittent current regime (De Raaf \& Boersma 1971).

Trough and planar cross-stratification imply movement of dunes and sand waves, respectively, with flow strength for dunes being somewhat higher than for sand waves. The low-angle troughs are comparable to the swaley cross-stratification defined by Leckie \& Walker (1982) in the Cretaceous of Western Canada. They seem to be scour and drape features, but different from hummocky cross-stratification, and they are thought to have been formed by high energy (storm) surf/breaker zone processes. The ultimate energy level is represented by the upper flow regime plane parallel lamination and the occurrence of parting lineation on bedding surfaces suggests that they were formed by traction currents. How 2 ever, if the massive character of some of the beds really is primary, this would require even higher flow velocities, with all the sand being brought into suspension.

The upward transition from lower flow regime ripples, sand waves and dunes to dominantly upper flow regime plane parallel lamination is evidence of increased flow velocities or of decreasing water depths. Wave ripple capping and mud drapes on top of the cosets can be related to either of two mechanisms: (1) they might represent slack water periods in an environment dominated by high rates of sediment transport, or (2) they might be the product of waning flow conditions, with abundant suspended material now being deposited. In both cases sediment transport must have been intermittent, and certainly of longer duration than diurnal tidal cycles. The upward disappearance of these features may suggest more permanent high energy conditions. Supporting this notion is the frequent indistinct lamination in the upper part of Facies IB, which may refiect increased sorting ability.

The conglomeratic interbeds can be divided into two groups: (1) thin, non-erosive lenses/ interbeds, and (2) thick, erosively based, lenti- 
(a)

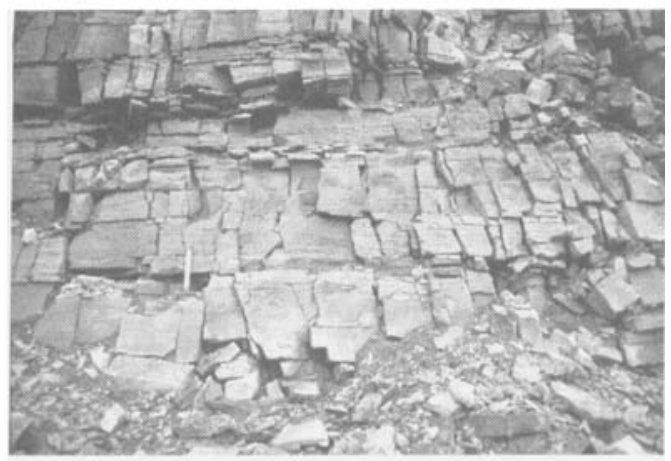

(b)

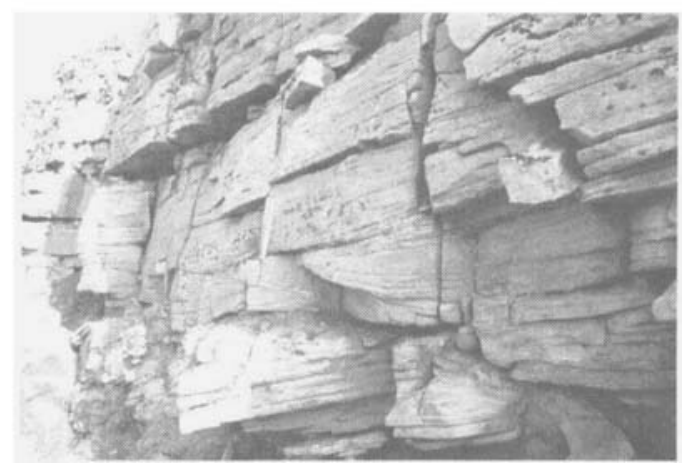

Fig. 11. Facies IB. (a): Plane parallel lamination cut by a low-angle trough. Note the more indistinct lamination upwards (Todalen N. E.). (b): Trough/hummocky cross-stratification passing upwards into plane parallel lamination. Note also zones of ripple lamination - mostly wave ripples (Longyeardalen E.). cular bodies of conglomerate. The first group is commonly $1-10 \mathrm{~cm}$ thick (average $2-3 \mathrm{~cm}$ ) and occurs as pebble concentrations on set boundaries (Fig. 8). These are observed all over the investigated area, but become increasingly important southeastwards, towards Svea. The second group (Fig. 8), which clearly comprises large scours or channelized features up to $2 \mathrm{~m}$ thick is observed only south of Reindalen, in the Svea area. These scours occur in the topmost part of Facies IB and are described in more detail under Facies IIA.

The uppermost $1-1.5 \mathrm{~m}$ of Facies IB are usually massive, due to intense rooting. However, traces of parallel lamination are frequently observed, and this part of Facies IB often has a distinct dark colour due to abundant diagenetic siderite. Two distinct types of roots have been recognized, one $0.5-1.0 \mathrm{~m}$ long, the other $5-10 \mathrm{~cm}$ long. These probably represent bush type and grass roots, respectively. The bush roots are the dominant type. Occasional Facies IB sequences contain rooted horizons several metres $(2-3 \mathrm{~m})$ below the top surface.

The organic content is generally low, but towards the top of the facies, moderate to high concentrations of organic debris are sometimes detected.

Only sporadic vertical shafts of Ophiomorpha nodosa, together with some Pelecypodichnus burrows on a few lower set surfaces, have been recognized in the Adventdalen area (Fig. 12). In

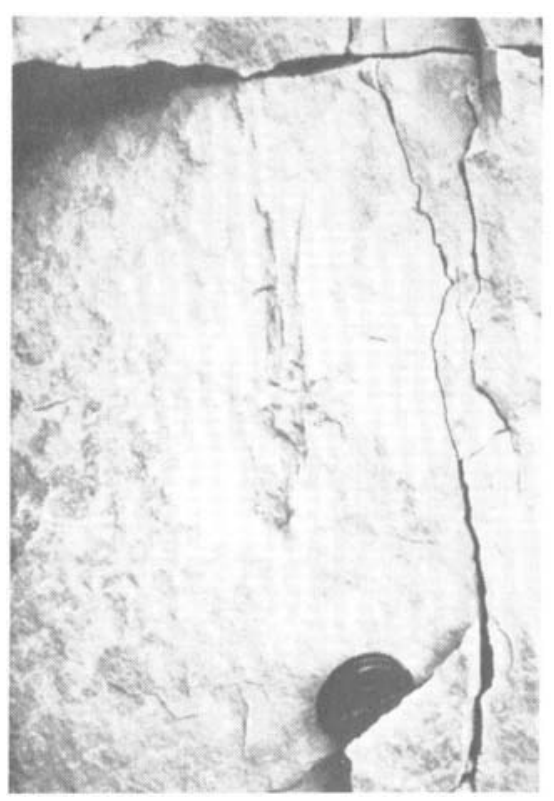

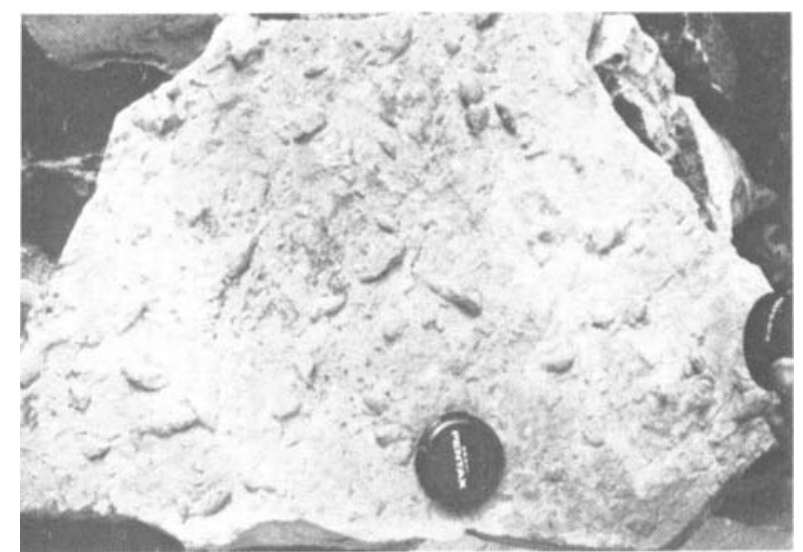

Fig. 12. Facies IB - biogenic structures, Adventdalen area. Left: Ophiomorpha nodasa burrow (Endalen N. W.). Right: Pelecypodichnus burrows on bedding surface (Endalen N.). 
the Svea area, as well as in the Reindalen and Kapp Laila boreholes, however, zones of intense bioturbation (Ophiomorpha nodosa) have been observed. These zones are commonly about $2 \mathrm{~m}$ thick, and are characterized by a gradual lower boundary, and an extremely sharp upper boundary. The sandstones below and above these zones contain scattered single, but much larger burrows of the same type.

Facies IB wedges out towards northeast, into non-marine shales and sandstones of Facies Association II, and towards southwest, into marine shales and sandstones of Facies IA. However, the facies is continuously developed in a northwest-southeast direction, along depositional strike, which gives it a diagnostic elongated, shore parallel geometry.

Within the exposed area, Facies IB is commonly capped by coals and shales of the delta plain facies association (Fig. 8).

\section{Environmental interpretation}

General. - The good sorting, relatively low degree of bioturbation and somewhat restricted assemblage of sedimentary structures within the finegrained sandstone facies (IB) are evidences of increased energy conditions, compared to those inferred for the underlying Facies IA. Hence, this facies is attributed to deposition in a moderate to high energy nearshore environment.

The sedimentary features and their vertical distribution are consistent with deposition in the part of the shoreface zone which is dominated by surf/breaker processes. The wave ripple lamination which is evidence of low physical energy conditions is related to fairweather processes.

Wave-formed ripples are typical of the fairweather seafloor of modern nearshore zones (Davis 1978). The plane parallel lamination and large-scale cross-stratification, on the other hand, are related to high-energy reworking and deposition. In the lower part of Facies IB, where these structures are associated with low-energy, wave ripple lamination, they probably represent highenergy storm conditions, with increased wave periodicities and wave heights causing the waves to break much earlier and hence lowering the surf zone. The uppermost part of the facies, however, was most likely being constantly reworked by fairweather surf zone processes.

The 'sheet-like' character of many of the thin conglomeratic interbeds (group 1) is typical of marine reworked gravel (Clifton 1973), and their abundant occurrence through Facies IB suggests that they were transported by infrequent, large storm waves, and left behind as post-storm, gravel lags. The lenticular form of the second group of conglomerates, on the other hand, points to a fluvial origin (see Facies IIA) suggesting that in the Svea area the beach was cut into by numerous small and intermediate size streams.

Although commonly rooted, the uppermost part of Facies IB shows few diagnostic signs of the low-angle, swash/backwash lamination typical of modern foreshore deposits (Hoyt \& Weimer 1963; Clifton 1969). Several explanations can be put forward; the most likely are: (1) due to the extensive rooting, typical foreshore lamination have extremely low preservation potentials, or (2) due to insufficient exposures and indistinct lamination, gently inclined bedding is incorrectly taken as horizontal. However, the frequently observed diagenetic siderite probably represents altered heavy minerals, and heavy mineral concentrations along laminae are a common feature of modern and ancient foreshore deposits (Clifton 1969; Harms 1975b). The occurrence of internal rooting may indicate some vertical stacking of facies.

Bioactivity is largely controlled by the rate of deposition, environmental energy, salinity, temperature and substrate composition (Frey 1978). In the case of Facies IB, no variations in substrate have been observed whereas sea water temperature and salinity may have varied both locally and seasonally. The environmental characteristics of Facies IB may also imply considerable variations in energy and of rate of deposition, suggesting that the zones of intense bioturbation recorded from the Svea area may represent periods of reduced winnowing and/or sediment accumulation. In the Adventdalen area, on the other hand, the general lack of bioturbation may indicate more persistent high energy conditions and continuous sediment transport. However, the possibility of overall decreasing salinities towards the north must also be considered (cfr. Fig. 19).

Wave characteristics. - As shown by Komar (1974, 1976), Clifton (1976), Allen (1979), Allen (1981), and several others, symmetric ripples may provide a clue to our understanding the character of the waves forming them. Although no detailed study of the symmetric ripples in Facies IB has been carried out, some general points can be made. 
The average ripple wave length is in the order of $10-20 \mathrm{~cm}$, and they are observed as much as $5 \mathrm{~m}$ below the topmost horizon. Following the arguments used for the plane parallel lamination in Facies IA, this is the maximum water depth at the time of deposition. And furthermore, the ripples are in sandstones of mean diameter of $200 \mu \mathrm{m}$.

The relationship between ripple length and orbital diameter $d_{o}$ is either (1) $\lambda=0.80 d_{o}$ (Komar 1974) or as for low orbital diameters (2) $\lambda=0.65$ $\mathrm{d}_{\mathrm{o}}$ (Miller \& Komar 1980). As the possible orbital diameters must be regarded as low, the relationship $\lambda=0.65 d_{o}$ may apply, and for these conditions the ripple spacing is independent of grain size corresponding to the field of orbital ripples of Clifton (1976). It is suggested that the ripples in question lie within the area of application of the linear Airy wave theory (Komar 1976, Fig. 3.17 ), and hence by taking a value of $15 \mathrm{~cm} / \mathrm{sec}$ for the threshold velocity (Ut), the respective wave period $(\mathrm{T})$ and wave height $(\mathrm{H})$ can be calculated, following the methods outlined by Komar (1974) and Clifton (1976). The T and H values corresponding to $\lambda=10 \mathrm{~cm}, \lambda=15 \mathrm{~cm}$, and $\lambda=20 \mathrm{~cm}$, are $3.2 \mathrm{sec}-0.56 \mathrm{~m}, 4.1 \mathrm{sec}-$ $0.29 \mathrm{~m}$ and $6.4 \mathrm{sec}-0.25 \mathrm{~m}$, respectively.

On this basis it can be concluded that the symmetrical ripples may have been formed by short (to intermediate) period waves $\left(T_{\max }=3.2-\right.$ $6.5 \mathrm{sec}$ ) with relatively low wave heights $\left(\mathrm{H}_{\max }=0.6-0.3 \mathrm{~m}\right)$. Such waves are commonplace today at the margins of enclosed or semienclosed seas, e.g. on the southern coast of Spain (Clifton 1976).

The wave period is closely related to windspeed and basin width, but as the palaeowindspeeds are unknown, it is impossible to give any accurate estimates of the fetch distance.

Palaeocurrents. - Within Facies IB there is a clear separation in palaeocurrent distribution between small-scale ripple lamination occuring on bedding surfaces, and large-scale internal cross-bedding. The dominantly wave-generated ripple lamination includes both symmetrical and asymmetrical ripple forms. As shown in Fig. 9, the symmetrical ripples have a northeast/southwest bipolarity, normal to the palaeoshoreline and the asymmetrical ripple forms are clearly inclined towards northeast, towards the palaeoshoreline. Also worth noting is the relatively high degree of dispersal within the symmetrical ripple palaeo- current distribution, compared to the asymmetrical ripple forms. The large-scale planar and trough cross-stratification which forms the secondary mode of cross-bedding (Fig. 9) also has a high degree of spread. A summary examination of the crossbeds, however, shows that they dip predominantly to the northwest, parallel to the palaeoshoreline.

The orientation of the crests of wave ripples is well known to be related to the direction of wave approach. Within this facies the wave ripple crests are oriented dominantly parallel to the palaeoshoreline, suggesting that the main direction of fairweather wave propagation was normal to the palaeoshoreline (Fig. 10). The dominantly landward inclination of the asymmetric ripple forms is evidence of an onshore velocity component generated by the velocity asymmetry commonly associated with shoaling waves (Clifton 1976).

The second mode of cross-bedding, the largescale structures, is interpreted as being generated mainly by storm surf zone processes, explaining the relatively high degree of spread. The clear northwestward component, however, strongly suggests the existence of northwestward flowing longshore currents (Fig. 10). This current direction implies that the storm waves approached the palaeoshoreline obliquely from the south. The fact that virtually no southeasterly directed palaeocurrent readings are recorded suggests that this was the main direction of storm wave approach, an interference supported by the suggested storm produced cross-bedding in the underlying Facies IA.

\section{Facies association II (delta plain/coastal plain)}

Facies Association II consists of shales, siltstones and coals interbedded with sandstones and conglomerates, and ranges in thickness from a few metres in the southeast (Svea area) to locally more than $20 \mathrm{~m}$ in the northeast (Adventdalen area).

The extensive coal development with local splitting and rejoining of coal seams, rooting, abundant channel fills and channel-related deposits, occurrence of inter-related marine/brackish water deposits, and the association with marine sediments below and above, suggest that Facies Association II accumulated in a paralic environment, which was characterized by a number of different subenvironments, both non-mar- 
ine and marine. The extent to which the sediments should be assigned to deposition on a coastal plain or delta plain will be discussed later.

Facies IIA - description and interpretation of processes

Facies IIA consists of light to dark grey, moderately sorted, fine to coarse-grained conglomeratic sandstones, and sandy conglomerates ranging from less than $2 \mathrm{~m}$ to more than $14 \mathrm{~m}$ in thickness and from a few tens of metres to more than $1 \mathrm{~km}$ in width (normal to palaeoflow directions). A rapid change in lithology and sedimentary structures, both vertically and laterally, is commonly recorded, but generally there is an overall fining upward trend. When exposed, the basal contact is clearly erosive, and a basal coarse member is sometimes developed. Internal scouring is observed in some of the thicker sequences, implying a complex, multistory pattern of infill. Fig. 13 shows the considerable variation in thickness, stratification and grain size encountered within a representative selection of Facies IIA sequences.
A wide range of primary (sedimentary) structures is recorded, the dominant being, in order of importance:

1. Large-scale, planar sets of cross-strata $(>5 \mathrm{~cm})$, with frequent occurrence of normal graded foresets and/or concentrations of pebbles on the lower boundary surface (Fig. 14).

2. Large-scale, trough cross-stratification (including scour and fill).

3. Plane parallel lamination.

4. Current ripple lamination.

Individual sets may be lenticular and of limited lateral extent, and are sometimes interbedded with thin, laterally impersistent drapes of organic-rich mudstone in between, but more commonly sets are subparallel, ranging from a few centimetres to more than a metre in thickness (average $0.3 \mathrm{~m})$. Thick sets $(<1 \mathrm{~m})$ of apparently structureless conglomerates and sandstones are also present, although indistinct and laterally discontinuous internal decimetre scale lamination/ grading is sometimes developed.

Large-scale, planar and trough cross-stratifi-

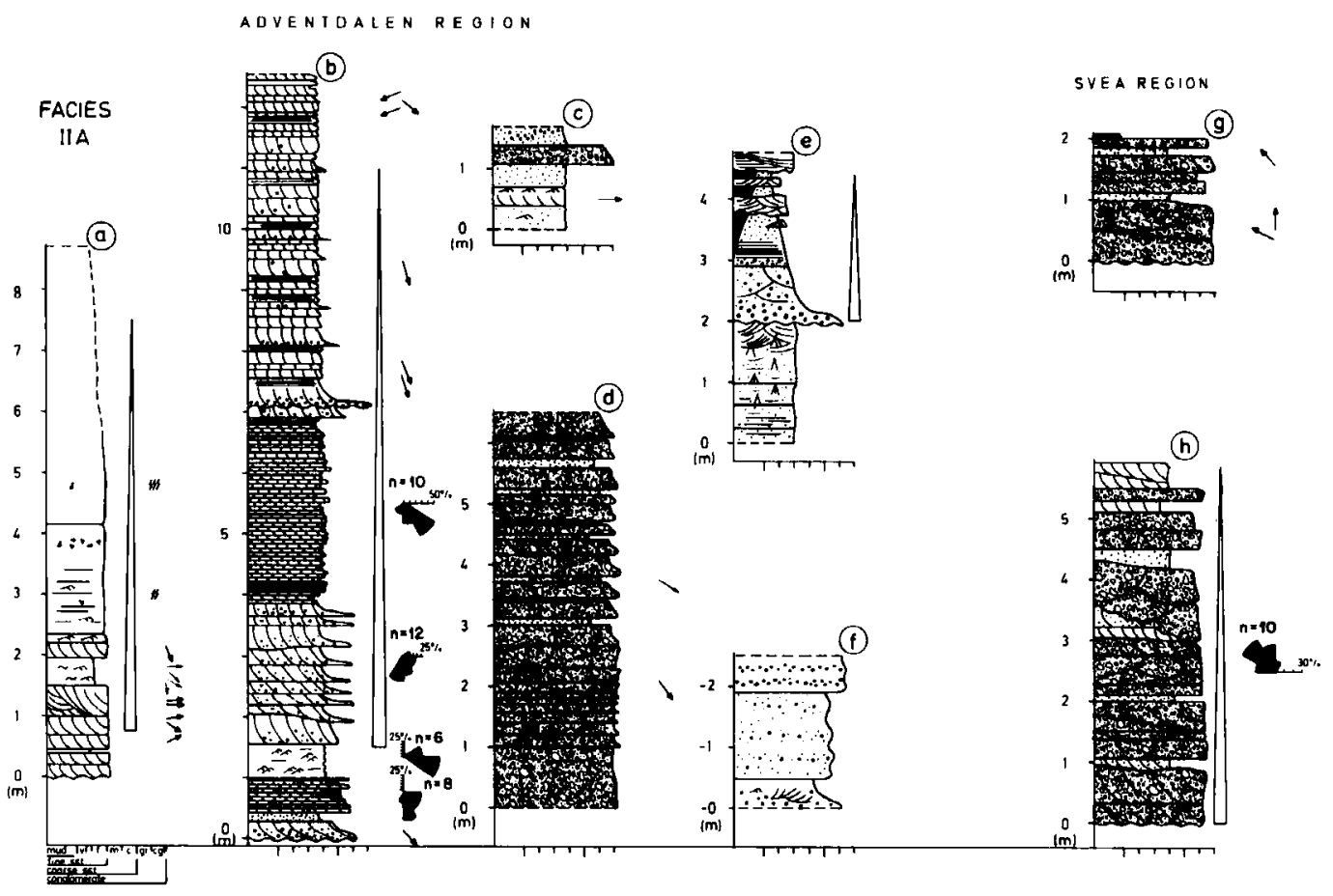

Fig. 13. Representative vertical sections through Facies IIA. (a): Lindholmhøgda N. (b): Louisfjellet W. (c): Todalen N. E. (d): Longyeardalen S. W. (e): Longyeardalen S. E. (f): Longyeardalen S. E. (g): Deinbolltoppane S. E. (h): Trollsteet N. 

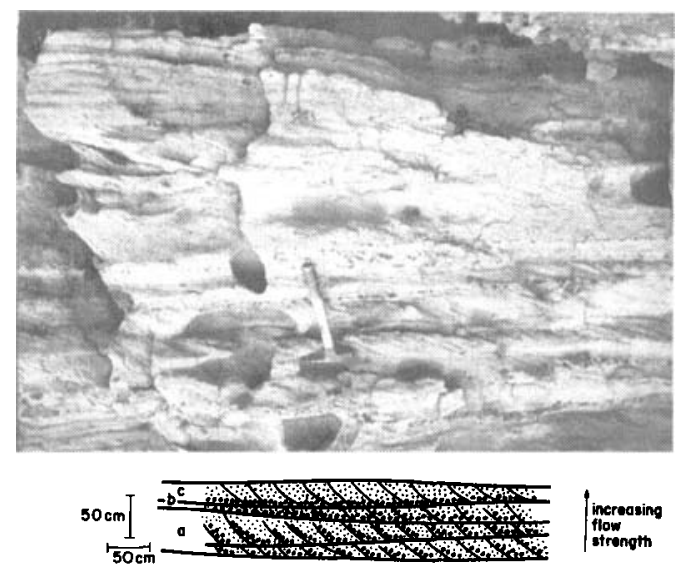

Fig. 14. Facies IIa. Planar cross-stratification with normal graded foresets and pebble concentrations on lower set boundaries in pebbly sandstone at Louisfjellet S. W. (Fig. 18b), and schematic illustration showing the relation to flow strength.

cation is evidence of sandwave and dune migration representing low to moderate flow conditions, and as shown by Allen (1965) normal grading within foresets is related to intermittent avalanching, commonly associated with relatively slow currents. More rapid flow will cause continuous avalanching and concentration of coarse material at the sandwave toe, producing a distinct 'lag' overlain by ungraded or poorly graded foreset laminae. The laterally discontinuous gradings within some of the otherwise apparently structureless conglomerates and sandstones may also be a product of differential sorting related to the intermittent avalanching process (e.g. Allen 1965, Fig. 13). Plane parallel lamination occurring in pebbly sandstones and conglomerates, associated with ripple lamination in more fine-grained counterparts may suggest lower flow regime conditions. However, where associated with planar sets of cross strata, in fine to medium grained sandstone, an upper flow regime origin is likely.

Facies IIA is commonly not bioturbated, though Fig. 13a shows a fining upward sequence with moderate to intense bioturbation in its upper part.

The topmost part of the facies is frequently penetrated by in situ rootlets, and sometimes capped by thin coals. The organic content is generally low to moderate, although moderate to high concentrations of plant remains may rarely be present. Scattered nodules of siderite are also observed.
Facies IIA is observed both in the Adventdalen and Svea regions, but not in the intervening area. It commonly occurs within the delta plain/coastal plain unit, below the uppermost Askeladden coal horizon. Around Svea, however, sandstones and conglomerates of this facies are sometimes directly associated with marine sandstones of Facies IB (see Fig. 8). And in Longyeardalen, some Facies IIA sandstones overlie and scour into the uppermost Askeladden coals.

In general, the Svea region is characterized by thinner, more coarse grained, and a larger number of Facies IIA sequences than the Adventdalen region.

\section{Environmental interpretation}

General. - The grain size, poor sorting compared to Facies Association I, erosional basal contacts, lenticularity normal to palaeoflow and association with non-marine shales, sandstones and coals, indicate that the sandstones and conglomerates assigned to Facies IIA may represent fluvial channel deposits. The rapid lithological and textural changes, both vertically and laterally, suggested large discharge variations, while the scarcity of fine grained sediments and frequency of erosion surfaces are evidence of rapid channel filling and abandonment.

Channel type. - None of the above features are diagnostic of rivers with high-sinuosity channel pattern. The abundance of planar cross-stratified sandstones and gravels, and frequent massive or crudely bedded gravels rather point to (though by no means are diagnostic of) channels of overall low sinuosity.

The distinction between low sinuosity and braided river channel fills is dependent upon careful analysis of the bar type present (Bluck 1976). The often poorly exposed channel fills within the Askeladden sequence do not yield information in such detail. However, the sometimes composite bodies of lenticular bedded and scoured fluvial gravels and sands (Fig. 13) probably reflect an overall braided river setting, while the subparallel, dominantly planar cross-stratified sands and gravels more commonly recorded may be attributed to both braided and low sinuosity river settings, with domination of sand waves and transverse bars. Limited bed or set thicknesses (20$30 \mathrm{~cm}$ ) suggest that many of the channel fills in question were accumulated in rather shallow, and 
possibly wide river systems (compare with Cant \& Walker 1976).

The bioturbated fining upward sequence in Fig. 13a occurs in close association with inferred tidally influenced deposits of Facies IID (see Fig. 17), and hence a marine influenced channel fill interpretation is suggested.

Fig. $13 \mathrm{~b}$ is an attempt to present the vertical palaeocurrent distribution within a single composite channel fill sequence in order to work out the directional properties for the various sedimentary structures. From field mapping, this particular sandbody has an apparently southeastward orientation, and is dominated by planar cross stratification of various scales. Although no obvious trends can be extracted, there is a general tendency for the smaller structures to be inclined in the direction of channel orientation, while the larger structures tend to be oriented at an angle to the main channel trend. The larger structures also seem to have a higher degree of dispersal. This is consistent with the bedform distribution in recent low sinuosity/braided streams, where large-scale cross-stratification is more variably oriented than ripple cross-lamination, which tends to be caught in major channel troughs and oriented along them (e.g. Bluck 1974).

The abundance of channel fills in the Svea region and their conglomeratic nature suggest a closer proximity to source area, compared to the Adventdalen region.

Palaeocurrents. - A few localities provide numer- ous cross-beds from which good, reliable palaeocurrent readings can be obtained. More often, however, a few ill-defined foresets are the only clues to palaeoflow directions.

The palaeocurrents are remarkably uniform and in the Adventdalen area the channel fills have a clear southeastward palaeocurrent distribution (Fig. 13 a-f), indicating the existence of a low angle palaeoslope in this direction. In the Svea area, the dominant palaeocurrent distribution is towards west-northwest, indicating a similar oriented palaeoslope (Fig. $13 \mathrm{~g}-\mathrm{h}$ ).

\section{Facies IIB - description and interpretation of processes}

Facies IIB consists of grey, poor to moderately sorted, silty, very fine to fine grained sandstones, commonly coarsening upwards from shales and siltstones. individual units are typically less than $4 \mathrm{~cm}$ thick (Fig. 15), with an apparent wedgeshaped geometry.

Ripple lamination dominates and in the upper part of some of the cosets there is sometimes climbing ripple lamination. The cosets are typically sharply based and average $0.2-0.3 \mathrm{~m}$ in thickness; although rare, up to $0.6 \mathrm{~m}$ thick cosets are observed. Between the cosets a thin mudlayer is frequently developed. Massive beds are also recorded, though these may actually be rippled.

The above suggests that individual cosets result from single unconfined flows spreading out on a
Fig. 15. Representative vertical sections through Facies IIB. (a): Hotellneset W. (b): Hiortfjellet S. W. (measured by $\mathbf{O}$. K. Hansen, 1980). (c): Helvetiafjellet $S$. W. (measured by $\mathrm{O}$. K. Hansen, 1980).

\section{FACIES II B}

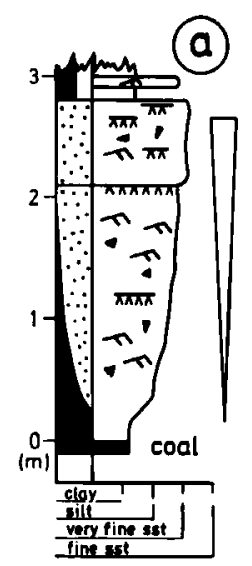

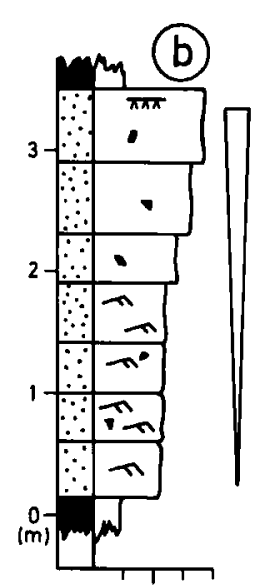

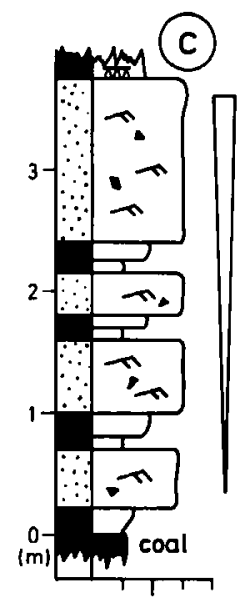


relatively flat surface. The ripple lamination reflects lower flow regime conditions, and the occurrence of climbing ripples towards the top of some of the cosets is evidence of increased sediment concentrations in the flow. Apparently massive beds may be the product of (a) silicification, (b) burrowing plants and animals, or (c) high energy, high sediment concentration flow and rapid deposition. Due to the general absence of high energy (upper flow regime) features, however, the latter explanation is least likely.

The top of Facies IIB is commonly penetrated by small roots $(<5 \mathrm{~cm})$, probably grass-roots, as are also rare individual beds, and moderate to high concentrations of drifted plant material are frequently recorded. The facies is sometimes bioturbated.

Facies IIB is commonly associated with, and pinches out into muds and coals (Facies IIC), and occasional units can be traced to pass laterally into fluvial channel deposits (Facies IIA). The facies comprises an important portion of the delta plain facies association in the Adventdalen northeast region, but southeastwards, towards Svea, it is of only minor importance.

\section{Environmental interpretation}

General. - Wedge-shaped sandstone units, laterally connected with fluvial channel deposits and pinching out into overbank fines, may be deposited by either of the following mechanisms:

1. Moderate overbank flooding and near-channel levee formation.

2. Severe flooding and formation of floodplain blanket sandstones.

3. Channelized levee breaking and crevasse splay formation.

The grain size, bed thickness, lateral continuity of beds, and the organization into coarsening upward units, suggest that most of the sandstones of Facies IIB resulted from crevasse splay type of deposition. A few thin-bedded, repeatedly rooted sandstone units may represent adjacent levee deposits, but generally, natural levees are hard to recognize.

Crevassing processes tend to provide abundant sediment in suspension, and climbing ripples are therefore commonly associated with this environment. Similarly, concentrations of drifted plant material into crevasse splay deposits are well known (Reineck \& Singh 1973).

Frequent rooting on top of individual units, but in general scarcity of internal rooting, suggest that the individual crevasse splay lobes built up fairly rapidly, until final abandonment and colonization by plants.

Palaeocurrents. - Due to poor exposures and indistinct lamination, rather few palaeocurrent readings were obtained from this facies. However, the palaeocurrents are clearly unimodal, and the ripple foresets appear to be inclined in the direction of depositional thinning/pinch-out.

Facies IIC - description and interpretation of processes

Light to dark grey shales and siltstones (occasionally sandy), and closely associated coals and coaly shales (Fig. 16), are the most voluminous facies within the delta plain facies association. They are continuously developed over most of the investigated area, and range from a few tens of centimetres to more than 10 metres in thickness. The primary bedding is commonly destroyed, due to bioturbation (or later weathering processes), hence the importance of bed load transport is impossible to evaluate. However, the fine grained nature of this facies implies a clear dominance of suspension deposition.

No marine burrows or fossil fauna have been recorded within this facies, but the sediments show evidence of extensive rooting, and plant fossils are common. Scattered concentrations of clay ironstone are sometimes recorded.

\section{Environmental interpretation}

General. - The coals, evidence of rooting, grain size and association with fluvial deposits (Facies IIA and IIB), indicate that Facies IIC was accumulated in a floodbasin environment adjacent to active channel belts. The extensive coal development is evidence of repeated abandonment of the floodbasins, probably due to river avulsion, and establishment of backswamp conditions.

Flood basins on recent lower coastal plains/ delta plains may be periodically covered by fresh or marine water forming shallow lakes or bays. Although the sediments in question may have been deposited partly subaqueously, no evidence 
Fig. 16. Representative vertical sections through Facies IIC. (a): Longyeardalen N. W. (b): Louisfjellet S. W. (c): Rudieaksla S. (measured by Arne Dalland, 1980). (d): Louisfjellet S. E. (measured by Arne Dalland, 1980).
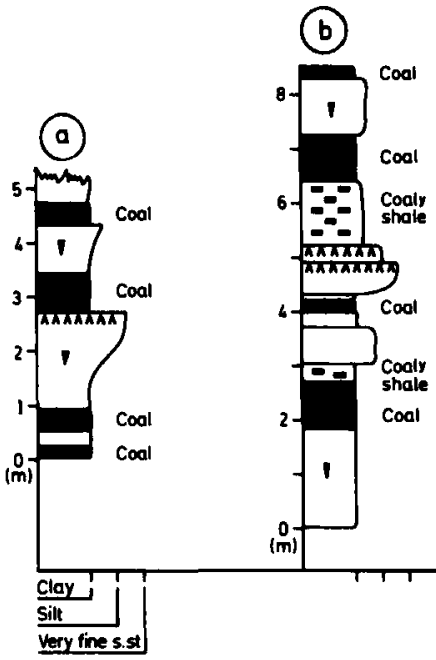

1

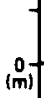

(m)

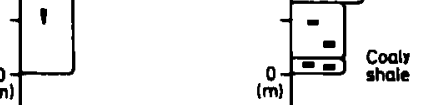

ery fine 5.5 (d)

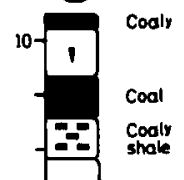

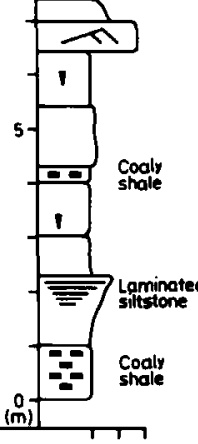

of brackish or saline bay conditions have yet been recorded.

However, the presence of tidal channels/sand flats (Facies IID - see below) strongly suggests some marine influence and tidal contribution also to overbank processes. It is likely that some of the distal muds and silts of Facies IIC may represent tidal mud flat deposits.

Coal. - In the Adventdalen area, the Askeladden sequence contains two main coal horizons, namely the Svarteper and Askeladden coal seams (Major \& Nagy 1972) (Figs. 2, 5). The Svarteper coal is usually directly overlying the delta front sand, but at some localities it is separated by a thin layer of organic rich shale/siltstone. The overlying Askeladden coal can be separated from the Svarteper coal by as much as $10 \mathrm{~m}$ of shales, siltstones and/or sandstones. However, very often the Askeladden coal directly succeeds the Svarteper coal, with no clear distinction. Both coal horizons show significant thickness variations, and often only one horizon is developed. The coal seams are usually split into several thinner argillaceous coal beds, and the quality is also impeded by a high sulphur content (Major \& Nagy 1972).

The underlying Longyear seam (Fig. 2), on the other hand, which has yielded most of the coal produced in this area, is of good quality. These coals, which show very little thickness variation and splitting compared to the Svarteper/Askelad-

den seams, are relatively clean, with sulphur concentrations between 1 and 2\% (Major \& Nagy 1972), which is less than half of the sulphur content in the Svarteper/Askeladden coals. The sulphur content increases and the coals become slightly argillaceous towards southwest (basinward).

The argillaceous nature, the rapid thickness variations and splitting of the Svarteper/Askeladden coal seams indicate that the coals were formed on frequently flooded, gently undulating delta plains. According to the model of Reidenouer et al. (1979), frequent flooding means that ferric iron $\left(\mathrm{Fe}^{3+}\right.$ as colloidal particles or absorbed on clays) is transported into the peat swamps, especially into topographic lows. When the peat grows over the clay partings, the ferric iron is reduced to the ferrous state $\left(\mathrm{Fe}^{2+}\right)$ and migrates into the adjacent peat, where sulphide is produced. When this occurs, some form of iron mono-sulphide, presumably marcasite or grengite is precipitated, which is later altered to pyrite. A more limited extent of the Askeladden delta plains compared to the underlying Todalen Member systems may also suggest that the Askeladden delta system in general was more prone to marine influence than were the underlying systems, implying more available sulphate to produce sulphide (Williams \& Keith 1979). It is suggested that the high sulphur content of the Svarteper/ Askeladden coals may be explained in this way. The persistent thickness and lateral continuity 
of the Longyear coal seam, on the other hand, suggests that it was accumulated on broad, gently subsiding delta plains characterized by extensive areas of marsh growth. The northeastern coal probably accumulated as proximal, fresh water marshes with almost no clastic influx, producing clean, homogeneous peats. Southwestwards, however, the gradual approach to marine water probably caused a change from fresh water to saline marsh growth, followed by an increase in clastic influx. As statistically shown by Williams \& Keith (1979) for the Allegheny coals of Western Pennsylvania, this may account for the observed southwestward increase in pyritic sulphur.

\section{Facies IID - description and interpretation of processes}

Facies IID occurs at several localities on the southern side of Adventdalen, in Endalen, Todalen and Bolterdalen, and at one locality on the southwestern end of the otherwise inaccessible Fuglefjellet (Fig. 4). The Adventdalen exposures appear to be interconnected, forming a laterally extensive sandstone unit. It consists of moderately sorted, very fine to fine grained sandstones alternating with shales/siltstones. On the southern side of Adventdalen units of this facies are commonly less than $5 \mathrm{~m}$ thick, displaying a sheet-like geometry, and although apparently gradational, field mapping suggests that the basal contact is in fact erosive (Fig. 17). Locally, the facies may attain typical concave-up, channel configurations, scouring as much as $12 \mathrm{~m}$ down into the shoreline/delta front sands (Facies Association I), and reaching a total thickness of $16 \mathrm{~m}$. On the Endalen west side (Fig. 4), such a deep scour is overlain by a $20-30 \mathrm{~cm}$ thick conglomerate consisting of quartz and chert pebbles, mud clasts, and abundant plant remains (Fig. 17). The Fuglefjellet exposure also shows basal scouring, overlain by a similar conglomerate.

The mud content is generally less than $10-15 \%$, increasing to perhaps $20-30 \%$ in the deep scour infills. The facies may be a coarsening upwards, fining upwards or in no trend at all. Stacked units within the deep scour infills also show both fining upwards and coarsening upwards characteristics. However, the overall vertical trend remains obscure. The facies are characterized by abundant ripple lamination, and subordinate large-scale cross-stratification and plane parallel lamination.
Silty and muddy intervals (especially in the deep scour infills) are dominated by flaser bedding, and also wavy and lenticular bedding. The ripples in question are often indistinct, due to bioturbation and probably also later cementation.

Current ripples predominate, but wave ripple forms are also present. Very commonly, however, the ripples have an intermediate current/wave ripple appearance, coming under the category of combined flow ripples (Harms 1975a) or modified ripples (Reineck \& Singh 1973). Ripple amplitudes are commonly between 1 and $3 \mathrm{~cm}$, and individual ripples are occasionally draped by organic debris, as are also internal ripple foresets. However, the deep scour infills tend to have predominantly low amplitude current ripple forms, and some extremely thin-bedded intervals yield ripple amplitudes on a millimeter scale.

Cosets range from 2 to $30 \mathrm{~cm}$ in thickness (average 5-10 cm), the thickness variations being very gradual, and they are commonly draped by thin clay/silt laminae. The cosets are commonly slightly dipping, or they may appear subhorizontal, and individual layers are laterally very continuous. In the deep scours, however, primary sedimentary dips of up to $20^{\circ}$ have been recorded. In the Endalen west sections (Fig. 17f), the direction of dip is approximately normal to sandbody extention.

Abundant ripple lamination implies dominantly low to moderate flow strengths, and the occurrence of combined flow ripples/modified ripples and wave ripples is evidence of an important oscillatory component. Mud draping and flaser/lenticular bedding indicate intermittent sediment transport.

Facies IID is overall moderately bioturbated, but although scattered escape burrows are encountered, no diagnostic trace fossils have been recognized. Body fossils have not been observed.

The facies is characterized by moderate concentrations of organic debris, and the topmost part is frequently penetrated by in situ roots. Thin lenses of siderite rarely occur.

The transition to overlying shales and silts of Facies IIC is commonly sharp, although a slight fining-upwards is sometimes observed.

\section{Environmental interpretation}

General. - The geometry, and erosive nature of the basal contact (Fig. 17) could suggest that Facies IID represents river channel deposits. The 


\section{FACIES II D}
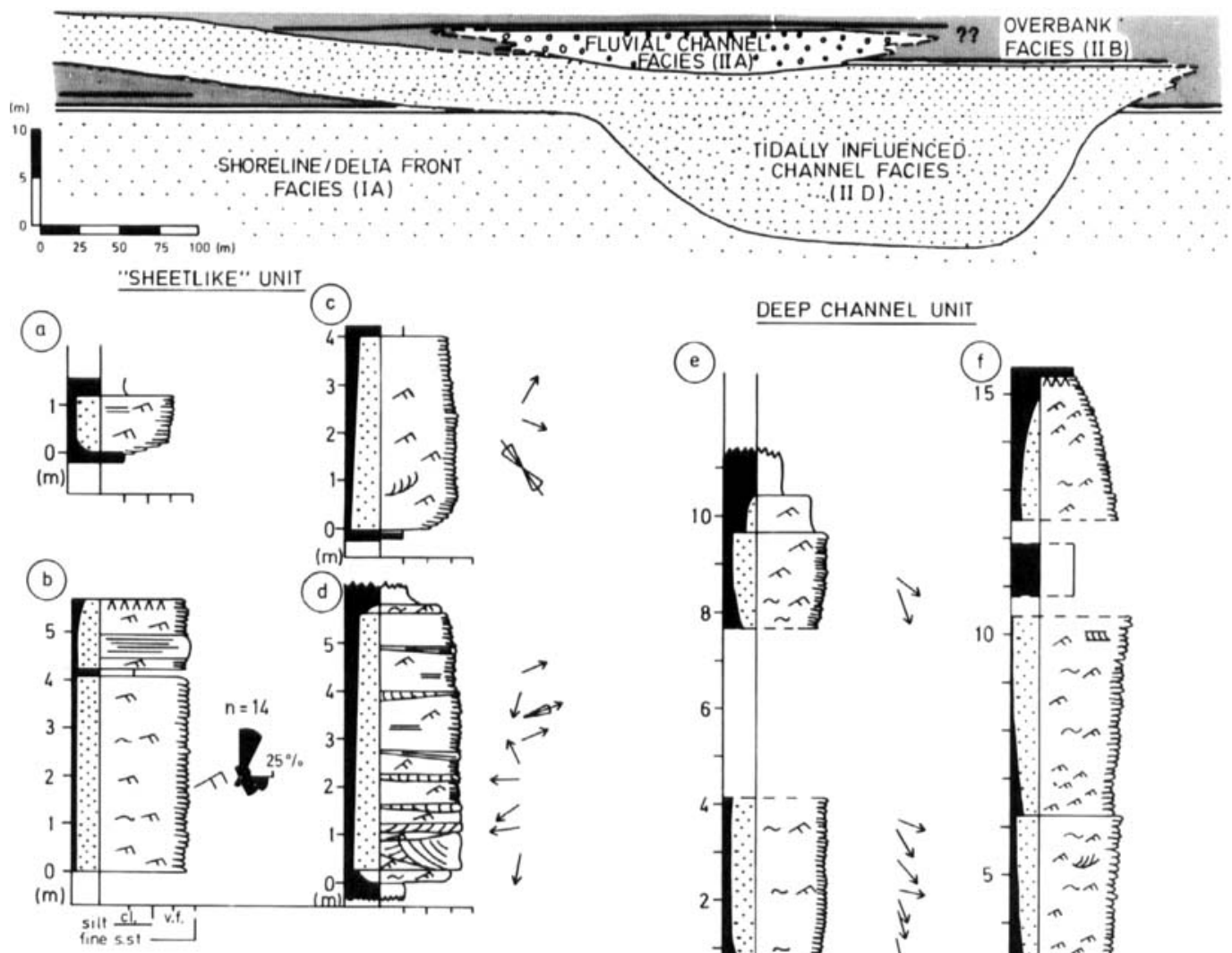

TOTAL

PALAEOCURRENTS FACIES II D

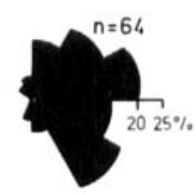

N

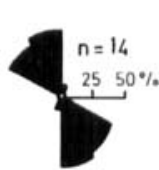

(e)

$\rightarrow$

\section{$\rightarrow$}

$\downarrow$

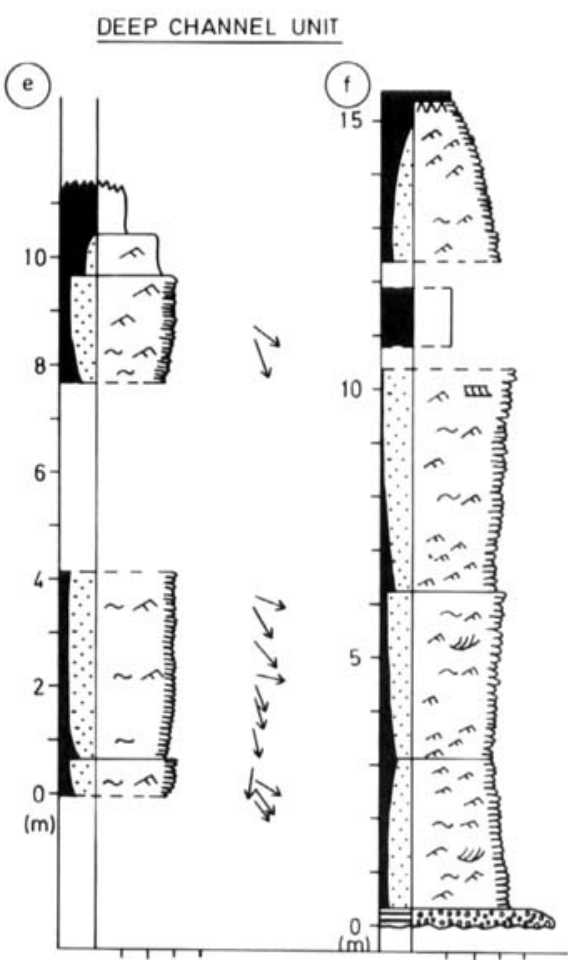

N-crest

Fig. 17. Schematic cross section (Endalen N. W.) and representative vertical sections through Facies IID. (a): Endalen E. (b): Endalen N. E. (c): Todalen N. W. (d): Todalen N. E. (f): Lindholmhøgda N. E. (g): Endalen N. W.

alternation of sands with clay/silts, however, strongly contrasts with the previously described channel sandstones and conglomerates of Facies IIA. The predominance of small-scale structures is evidence of dominantly weak currents, reflecting low gradients, and the primary sedimentary dip is interpreted as representing lateral accretion surfaces, suggesting a high sinuosity channel pattern.

However, assuming an overall coastal depo- sitional setting, the abundant evidence of biological reworking and common occurrence of wave and wave/current modified ripples would argue against an entirely fluvial origin. Hence, the intricate vertical organization, with both fining-upward and coarsening-upward sequences, abundant mud grade sediment comprising flaser/lenticular bedding, and the lateral continuity of individual layers, raise the question of the possibility of tidal contribution to channel 
processes (cfr. De Raaf \& Boersma 1971; Klein 1971; Reineck \& Singh 1973; Oomkens 1974; Ginsburg 1975; Howard et al. 1975). The clay content and ripple type distribution are clearly related to channel depths, with abundant flaser/ lenticular bedding and current ripple forms dominating in the deep scours and wave/wave modified ripple forms predominating in the shallow parts. This is also known to be a common feature within the lower reaches of recent tidal channels (Reineck \& Singh 1973). Palaeocurrent studies do not confirm the presence of tidal currents, however, although at one locality a vague directional bimodality is present (see below).

It is concluded, though, that Facies IID has been influenced by tidal processes. A proper tidal channel/sandflat origin is not proved, so a tidally influenced fluvial channel interpretation is probably more acceptable. The width and depth values are comparable to those of many recent estuarine/tidal channel systems (Reineck \& Singh 1973; Oomkens 1974), and although these relationships do not yield diagnostic information about palaeotidal range, some interesting points can be made. In the Niger Delta, as well as in the German Bay, 2-3 m tidal fluctuations produce tidal channel depths of up to $20 \mathrm{~m}$. This means that channel depths of $15 \mathrm{~m}$, which is the maximum depth of the channels in question, do not necessarily imply high tidal ranges. A tidal range of $1-2 \mathrm{~m}$ (microtidal settings) would probably suffice.

At the northeastern end of the Fuglefjellet cliffs (Fig. 4) a thick channel-fill sequence, resembling many of the large-scale characteristics of the above facies, can be seen. However, the exposure is inaccessible, and a similar interpretation can only be speculative.

Palaeocurrents. - Within the exposures on the southern side of Adventdalen, ripple foresets are inclined predominantly towards the southeastnortheast, and the bipolar symmetric ripples show a similar orientation (Fig. 17). At one locality (Fig. 17d) counter-oriented, large-scale structures are present, indicating current reversals.

Unfortunately, the lateral continuation of the facies is not known, causing difficulties in interpreting the palaeocurrent directions. As an illustration, a southwestward extension would favour a flood-dominated estuarine interpretation, while a southeastward extension would favour an ebb-dominated tidal-tidally influenced channel/ tidal sandflat interpretation (Fig. 17). However, the palaeocurrents are so far poorly understood, and the choice of any particular model is avoided.

\section{Delta type and palaeogeography}

Modern deltas are discrete shoreline proturberances formed where rivers enter the sea, lagoons or freshwater lakes (Elliott 1978). In ancient sequences, however, coastal protuberances cannot easily be recognized, the distinction between deltaic and clastic shoreline deposition being dependent upon evidences of fluvial input. Askeladden sequence contains abundant fluvial sandstones and conglomerates; hence a clear deltaic setting is inferred.

In this context the shoreline sandstones of Facies Association I may be regarded as delta front deposits. These delta front sheet sands have few indications of primary fluvial processes. The sediments are completely reworked and redistributed by marine processes, waves in particular. The evidence for tidal reworking is only circumstantial, and by no means of major importance. Following the delta classification scheme outlined by Galloway (1975), the Askeladden delta system would plot as wave-dominated, with some possible tidal influence.

Fig. 18a-g shows some simplified cross sections along the northeastern margin of the Central Tertiary Basin, suggesting that the Longyearbyen-Svea region was characterized by a northwest/southeast oriented palaeocoastline (see p. 25), as also suggested by Kalgraff (1978). The occurrence of non-marine shales and sandstones and coals on the northern side of Isfjorden and also along the northwestern margin of the Central Basin in the Grønfjorden area (Fig. 4), suggests that the coastline curved, forming a large bay towards northwest (Fig. 19). South of Svea, the Askeladden sequence thins abruptly (Fig. 18, S1) against an inferred east-west oriented high (van Mijenfjorden Fault Block, Fig. 6) (see p. 25). Although the high was more or less submerged at the time of Askeladden deposition, and did not much affect the coastline in Fig. 19, a submarine relief is likely to have persisted in Askeladden times.

The association of fluvial conglomerates and shoreface/beach deposits in the Svea region (Fig. 8) is interpreted in terms of a fan delta setting. It is suggested that the area was fed by nearby alluvial fans to the east and southeast (Fig. 19). 


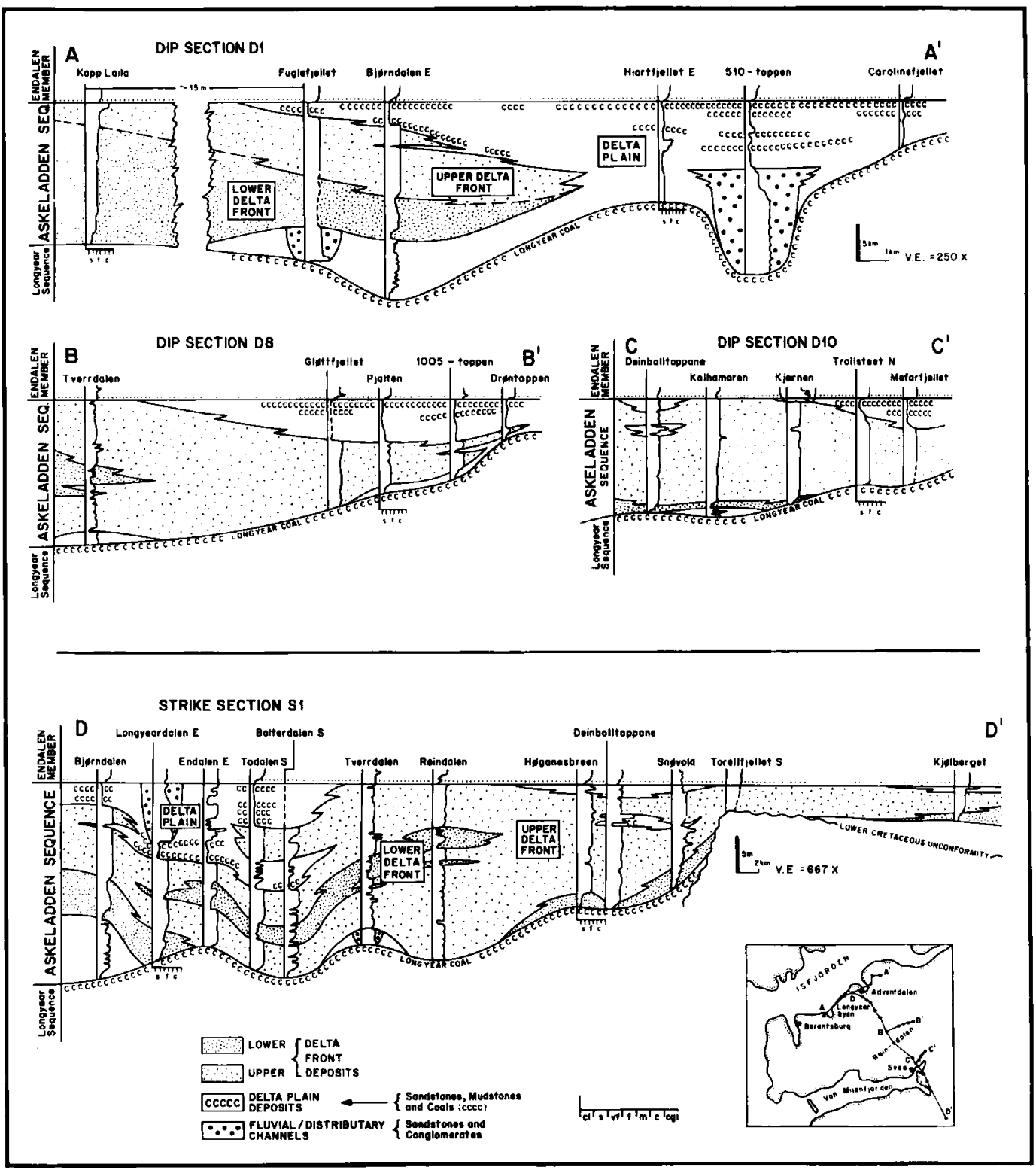

Fig. 18. Generalized cross sections of the Askeladden sequence along the northeastern margin of the Central Basin. Note the rapid N.E.-S.W. facies change. Note also difference in scale between dip and strike sections.

However, the fan model is strictly hypothetical, based only on grain size and inferred high gradients, suggesting short-headed stream systems here (see Facies IIA).

The morphology of the deltaic system farther north in the Longyearbyen area is also necessarily speculative, but here it is less obviously fandeltaic, despite the coarsness of some of the sedi- ments. The basin here was fed by rivers from the north, possibly with a major depocentre in the eastern Isfjorden area (Fig. 19). The clear southeasterly palaeocurrents in the Longyearbyen area are somewhat problematic on account of the inferred regional southwesterly palaeoslope. This apparent anomaly is probably due to the Longyearbyen measurements representing the eastern 


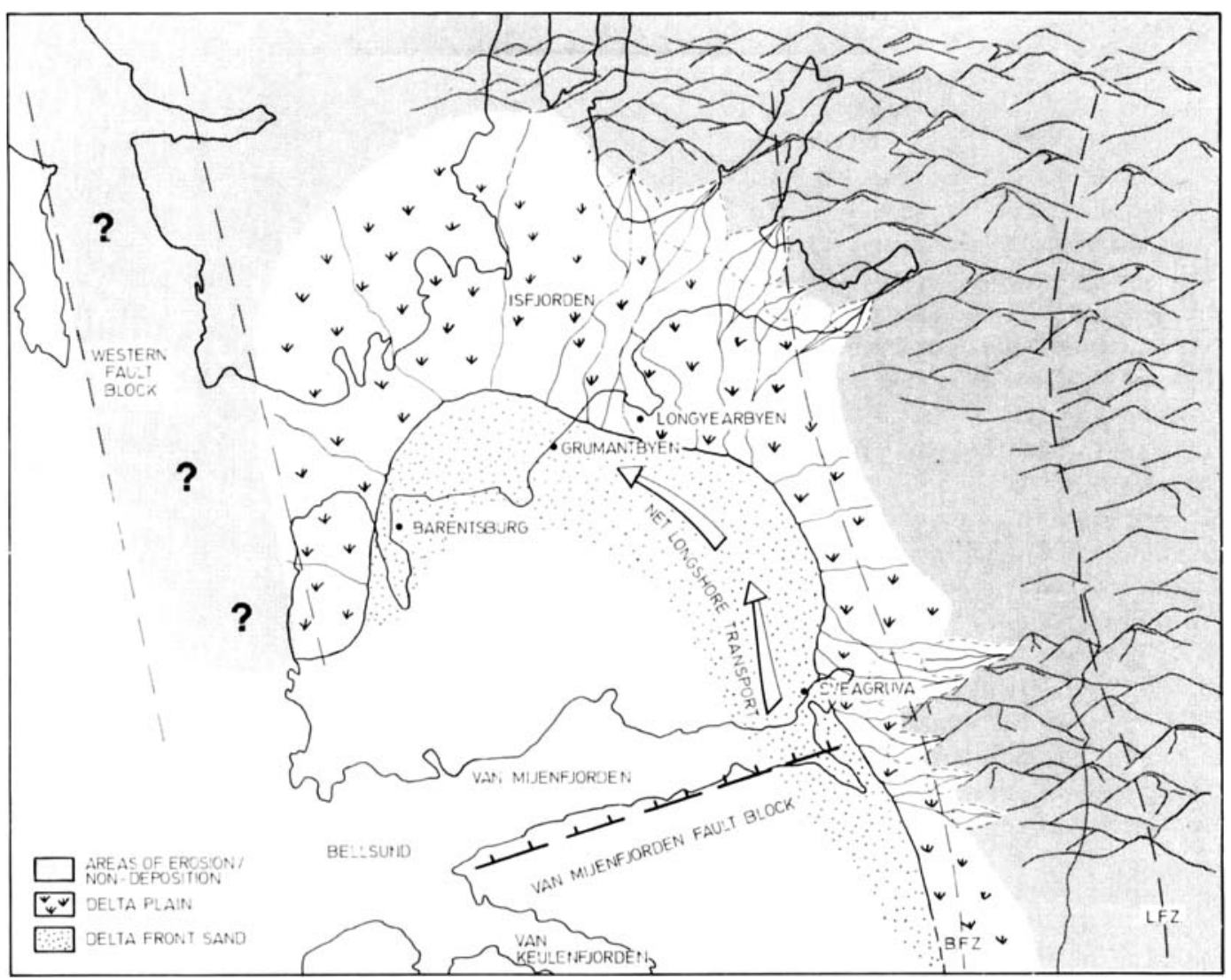

Fig. 19. Generalized palaeogeography and palaeonvironment of the Askeladden sequence. B.F.Z. = Billefjorden Fault Zone. L.F.Z. = Lomfjorden Fault Zone.

flank (with a southeastern component of slope) of the southerly prograding Isfjorden delta system.

The above considerations suggest that the eastern margin of the Askeladden Basin was characterized by two point sources or two areas of delta outbuilding, one in Isfjorden and one beyond the eastern end of Van Mijenfjorden. The relative lack of fluvial deposits in the delta plain succession between the Adventdalen and Svea regions tends to support the above notion, but could, of course, also be due to data limitation. Regional palaeocurrent patterns are the main basis of the basinal model proposed.

The concept of point sources implies considerable redistribution/longshore transport of sediment into the areas of minor sediment input. As indicated by the facies analysis, the longshore currents were dominantly flowing northwestwards, indicating net sediment transport from southeast toward northwest, into the large, northern bay (Fig. 19).

\section{Controls on deltaic sedimentation - discussion}

\section{Source area}

The Askeladden sequence sandstones contain abundant quartz and only minor feldspars and micas; the conglomerates are composed almost exclusively of quartz and chert clasts indicating a sedimentary provenance. Coarse sandstones and conglomerates are especially abundant in Lower-Middle Carboniferous and Lower Cretaceous rocks from all around the Central Tertiary Basin (Cutbill \& Challinor 1965; Holliday \& Cutbill 1972), allowing few or no constraints on source area. 


\section{Receiving basin}

In terms of receiving basin configuration, the Askeladden sequence was deposited in a fairly narrow structural trough which was open to the south (Fig. 5, 19). The rivers supplied sediment both across the eastern side and in along the axis from the northein end of the trough. As can be estimated from cross sections (Fig. 18), the Nordenskiöld Land sub-basin was characterized by very gentle offshore slopes, generally much less than $1^{\circ}$, and the maximum water depth is not considered very much greater than $25-30 \mathrm{~m}$, which is the inferred maximum thickness of the delta front sands.

The size of the basin is approximately $3 \times 10^{9} \mathrm{~m}^{2}$ (Figs. 5, 19), and an average thickness of the Askeladden sequence of $20 \mathrm{~m}$ gives a total volume of sediment infill of approximately $60 \times 10^{9} \mathrm{~m}^{3}$, or 120 billion metric tons. By comparison, the Mississippi Delta system (Coleman \& Wright 1975) would supply this sediment volume in only 500 years, while the Po River Delta in Italy (Nelson 1970) would need 6,000 years, and the small Guadalupe Delta in Texas (Donaldson et al. 1970) 120,000 years. In making such comparisons it is worth remembering that it has already been suggested that the Askeladden delta complex was partly a fan delta complex. The comparatively moderate sediment volume should thus be seen in this light.

According to recent palaeontological and palynological work, the Firkanten Formation is of early Palaeocene (Danian?) age (Vonderbank 1970; Manum \& Throndsen 1978a), whereas the

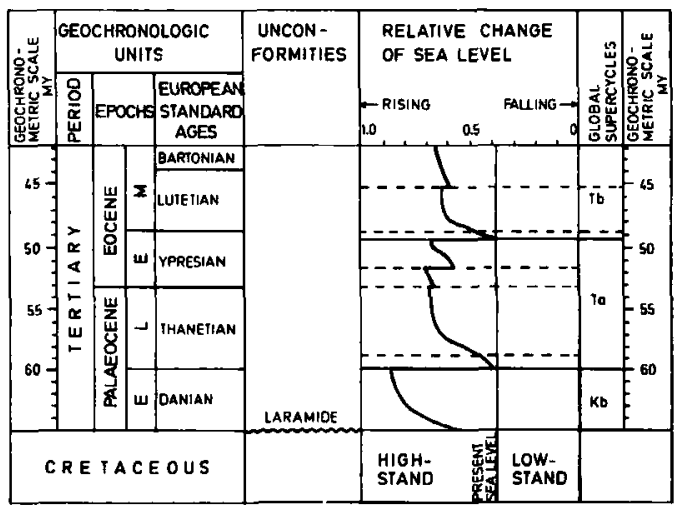

Fig. 20. Global chart of relative sea level changes (after Vail et al. 1977). Note the long-term early Palaeocene sea level rise, and the abrupt sea level drop at the Danian/Thanetian (mid Palaeocene) boundary.
Grumantbyen Formation (Fig. 2) (Steel et al. 1981 ) is probably late Palaeocene in age (Manum \& Throndsen 1978a). As the boundary between early and late Palaeocene is globally defined by an abrubt sea level drop (Fig. 20), this should be reflected also in the Spitsbergen succession. The most obvious place to locate this event is at the base of the widespread, regressive Grumantbyen Formation. The concept of an early/late Palaeocene boundary at the base of the Grumantbyen Formation leaves a maximum time span of about 5 million years (Fig. 20) for the deposition of Firkanten and Basilika Formations. In the northernmost (proximal) exposures in the Reindalen area, the Basilika Formation (Fig. 2) comprises approximately 17 thin, but laterally continuous coarsening upward sequences which may be regarded as facies-equivalent (distal) to the deltaic units of the Firkanten Formation. Eight additional deltaic sequences within the Firkanten Formation proper give a total number of 25 deltaic units in the early Palaeocene succession. Assuming approximately equal time of deposition, and using the above time figure of 5 million years, a maximum time of deposition of 200,000 years/ unit is calculated. Depending on the length of the transgressional events, however, the actual time of deposition may be considerably less. Still, although by no means diagnostic, rather slow rates of sedimentation are indicated, which are consistent with an overall fan delta type of setting.

The extensive reworking of the Askeladden delta front unit by marine processes implies that basinal energy exceeded sediment input. Although the actual basin shape commonly favours the generation of strong tidal currents (Coleman \& Wright 1975), the tidal contribution to Askeladden delta front processes is considered of minor importance (see p. 41). And the shallow water depths and possible submarine relief as provided by the Van Mijenfjorden fault zone would be expected to cause some filtering of wave energy. Large, open oceanic swells probably did not therefore reach the shoreline, although as indicated in the facies analysis intermediate period storm waves were possibly not uncommon. On this basis it is suggested that the extensive reworking of Askeladden delta front sands is related to low to moderate sediment influx rates, rather than to extreme basinal energy. Again, this is more readily acceptable in the light of point source supply by fan deltas.

The dominant northerly storm wave approach 
(Fig. 10) may be related to basin shape and orientation (cfr. Figs. 5, 19). The narrow basin provided small fetch distances for westerly, easterly and northerly storm winds, compared to those coming from the south. And there might also have been a tendency towards major storms being generated in the open sea to the south.

Due to lack of faunal criteria, the salinity of the receiving basin water mass is impossible to evaluate. However, the outlined basin configuration is favourable of periodic fresh water dilution, e.g. during large floods. Especially in the north, this effect may have caused a 'high stress' environmental with strong negative effects on the infauna.

\section{Climate}

The abundant coals and coaly shales in Todalen Member are evidence of highly vegetated, poorly drained flood plains/delta plains, and indicate an overall moist climate, highly conducive to the net preservation of organic material. There are few temperature indicators in the Spitsbergen early Palaeocene rocks, but in the above late Palaeocene (former Eocene) deposits, evidence of ice-rafting implies low winter temperatures (Dalland 1977).

According to continental drift reconstructions (Irving 1977), Svalbard was situated somewhere between 65 and $70^{\circ} \mathrm{N}$, immediately north of Greenland, during the Palaeocene. As Palaeocene is prior to the separation of the Barents Shelf and East Greenland, and the NorwegianGreenland Sea was not more than a narrow seaway (Fig. 5) with no warm North Atlantic Current circulating (see also Dalland 1977), the Palaeocene climate on Svalbard was probably of the continental type, with warm summers and cold winters.

Such temperatures, however, suggest freezing and trapping of water during the winter months, and melting and release of water during the summer period, indicating significant seasonal discharge variations. On this basis it is suggested that the Askeladden delta system received its major sediment load during the summer period. Basinal reworking and redistribution (longshore transport), on the other hand, probably intensified throughout the winter months, with heavy winter storms frequently striking the coastline.

Temporal discharge distributions, combined with dominance of mechanical weathering due to overall low temperatures, commonly favour unstable low-sinuosity/braided channel patterns and high bed load/suspended load ratios (cfr. Coleman \& Wright 1975). This suggests that climate may have been a contributory control also on the Askeladden fluvial systems.

\section{Tectonics}

On the basis of thickness variations within Todalen Member across Adventdalen, Steel (pers. comm.) postulated a syn-sedimentary basement fault running along this valley. But subsequent sedimentological and seismic work seem to show that the thickening across this valley is purely facies related. Neither has any other evidence of major tectonic disturbances within the Askeladden sequence so far been recorded, although minor syn-sedimentary deformational structures do occur. The concept of a fault-bounded Palaeocene Central Basin trough, however, implies that tectonics should have exerted some control on sedimentation, though probably on a larger scale.

The fact that the Longyear coal over large areas is directly overlain by Askeladden delta front sediments, strongly suggests that the drowning of the former Longyear delta system occurred more or less simultaneously along the northeastern margin of the Central Basin. The lack of a transgressive erosion surface and lag immediately above the coal seam may also suggest that the Longyear peat swamps were rapidly transgressed, rather than slowly drowned (see Sanders \& Kumar 1975; Heward 1981). It is thus suggested that the transgression of the Longyear delta system was in response to rapid basin downwarp against the marginal faults rather than to eustatic sea level rise or autocyclic delta shifting. A similar mechanism is likely to explain the transgression of the Askeladden delta system.

Apart from affecting basin subsidence and hence delta progradation and abandonment, the coarse-grained nature of the Askeladden fluvial deposits, compared to those of the underlying Todalen Member delta systems, may suggest that tectonics also caused rejuvenation and uplift of source area in Askeladden times.

\section{Summary and conclusions}

The very extensively developed Longyear coal seam marks the abandonment of the former 
Longyear delta lobe (Fig. 2). After this period of peat accumulation the basin suddenly subsided, and the sea transgressed rapidly onto the flat marshland. The transgression extended eastwards beyond Svea, and northeastwards some kilometres beyond Longyearbyen (Fig. 4). The main outstanding sheet sandbody of the Askeladden sequence was deposited as a prograding shoreline/delta front unit, from offshore/lower shoreface shales, silts and very fine sands, to upper shoreface/foreshore fine to medium sands (Fig. 8). The facies analysis indicates a high wave energy shoreline, with some possible tidal influence, and from cross sections (Fig. 18) a general northeast to southwest direction of progradation is inferred. Palaeocurrent analysis indicates periodically strong longshore currents flowing towards the northwest, probably causing significant alongshore transport and redistribution of sediments (Fig. 10). The above considerations suggest wave-(tide) dominated delta conditions.

The Askeladden basin was a shallow, lowgradient basin, and estimates of ancient wave conditions suggest the presence of both short period (fairweather) waves and intermediate period (storm) waves (Fig. 10). Tidal motions were probably within the micro- (meso)-tidal range. The overall basinal energy is considered moderate, and the extensive winnowing and redistribution of the delta front sediments are thought to reflect low rates of sediment input. Independent considerations on time of deposition support this notion.

Behind the Askeladden shoreline, highly vegetated swamps and marshes accumulated and fixed the beach deposits below. Within the outcrop area, the non-marine deposits are clearly fluvial dominated, formed on delta plains of moderate to high gradients. Abundant coal development suggests an overall moist climate, and the high-latitude position of the Spitsbergen Palaeocene $\left(65-70^{\circ} \mathrm{N}\right)$ (Irving 1977) suggests low winter temperatures, which may have caused seasonal discharge variations. In the north (Adventdalen area), the delta plain was cut into by a hierarchy of fluvial and occasional tidal/tidally influenced channels, giving dominantly south-southeasterly palaeocurrent directions. In the southeast (Svea region), the dominant direction of fluvial transport was towards northwest, suggesting that the basin received sediment mainly from two point sources, one east of Svea, and one in the inner Isfjord area (Fig. 19). The composition of the sandstones and conglomerates indicates a sedimentary provenance.

The tectonic control on early Palaeocene sedimentation on the Svalbard Platform is well documented (Steel et al. 1981) and relates to transtensional/oblique slip movements along the Greenland/Barents Block boundary. It is suggested that the early Palaeocene basin was fault bounded, a graben or half graben whose floor was broken up into several southerly tilted fault blocks (Fig. 5). Rapid basin downwarp against these marginal faults was probably the main control on delta abandonment and transgression.

Acknowledgements. - This work is part of the University of Bergen's project on the coal-bearing rocks of Spitsbergen. It has been supported financially by Norges Teknisk Naturvitenskaplige Forskningsrald (NTNF), the Norwegian Petroleum Directorate (NPD), and Statoil. I am grateful to Ronald Steel, for suggesting and supervising the work and for stimulating discussions, and to Arne Dalland, for extensive field co-operation and discussions. I am also indebted to them for critically reading through the manuscript and for making comments and suggestions. Thanks finally to Store Norske Spitsbergen Kulkompani (SNSK), especially Alv Orheim and Axel Stensrud, for their extensive help with transport and accommodation on Spitsbergen, to Dag Bergslien for assitance in the field, to the drawing offices at Norsk Hydro, Sandvika, and to the Geological Institute, Dep. A, University of Bergen, for drawing assistance.

\section{References}

Allen, J. R. L. 1965: Sedimentation in the lee of small underwater sand waves: an experimental study. J. Geol. 73, 95116.

Allen, J. R. L. 1979: A model for the interpretation of wave ripple-marks using their wave length, textural composition and shape. J. Geol. Soc. Lond. 136, 673-682.

Allen, P. A. 1981: Wave-generated structures in the Devonian lacustrine sediments of south-east Shetland and ancient wave conditions. Sedimentology 28, 369-379.

Atkinson, D. J. 1963: Tertiary rocks of Spitsbergen. Am. Ass. Petrol. Geol. Bull. 47, 302-323.

Banks, N. L. 1973: Innerelv Member: Late Precambrian marine shelf deposit, East Finmark. Norg-geol. Unders. 288, 7-25.

Birkenmajer, K. 1972: Tertiary history of Spitsbergen and continental drift. Acta Geol. Polonica 22, 193-218.

Bluck, B. J. 1974: Structure and directional properties of some valley sandur deposits in Southern Iceland. Sedimentology $21,533-554$.

Bluck, B. J. 1976: Sedimentation in some Scottish rivers of low sinuosity. Trans. $R$. Soc. Edinburgh 69, 425-456.

Cant, D. J. \& Walker, R. G. 1976: Development of a braided-fluvial facies model for the Devonian Battery Point Sandstone, Quebec. Can. J. Earth Sci. 13, 102-119.

Clifton, H. E. 1969: Beach lamination - nature and origin. Mar. Geol. 7, 553-559.

Clifton, H. E. 1973: Pebble segregation and bed lenticularity in wave-worked versus alluvial gravel. Sedimentology 20 , 173-187. 
Clifton, H. E. 1976: Wave-formed sedimentary structures: a conceptual model. In Davis, R. A. Jr. \& Ethington, R. L. (Eds.): Beach and Nearshore Sedimentation. Spec. Publ. Soc. Econ. Paleont. Miner. Tulsa 24, 126-148.

Coleman, J. M. \& Wright, L. D. 1975: Modern river deltas: Variability of processes and sand bodies. Pp 99-149 in Broussard, M. L. (Ed.): Deltas, Models for Exploration. Houston Geol. Soc.. Houston.

Collinson, J. D. 1978: Alluvial sediments. Pp. 15-60 in Reading, H. G. (Ed.): Sedimentary Environments and Facies, Blackwell Scientific Publications.

Cutbill, J. L. \& Challinor, A. 1965: Revision of the stratigraphical scheme for the Carboniferous and Permian rocks of Spitsbergen and Bjørnøya. Geol. Mag. 102, 418-439.

Dalland, A. 1977: Erratic clasts in the Lower Tertiary deposits of Svalbard - evidence of transport by winter ice. Nor. Polarinst. Årbok 1976, 151-166.

Davis, Jr., R. A. (Ed.) 1978: Coastal Sedimentary Environments, Springer Verlag, New York. 420 pp.

Donaldson, A. C., Martin, R. H. \& Kanes, W. H. 1970: Holocene Guadalupe delta of Texas Gulf Coast. In Morgan, J. P. \& Shaver, R. H. (Eds): Deltaic Sedimentation, Modern and Ancient. Spec. Publ. Soc. Econ. Paleont. Miner., Tulser 15, 107-137.

Elliott, T. 1978: Deltas. Pp. 97-143 in Reading, H. G. (Ed.): Sedimentary Environments and Facies, Blackwell Scientific Publications.

Flood, B., Nagy, J. \& Winsnes. T. S. 1971: Geological Map Sheet IG, Spitsbergen Southern Part. Nor. Polarinst. Skr. $154 A$.

Frey, R. W. 1978: Behavioral and ecological implications of trace fossils. Pp 46-73 in Basan, P. B. (Ed.): Trace Fossil Concepts. Soc. Econ. Paleont, Miner. Short Course no. 5 , Oklahoma City.

Galloyway. W. E. 1975: Process framework for describing the morphologic and stratigraphic evolution of deltaic depositional systems. Pp. 87-98 in Broussand, M. L. (Ed.): Deltas, Models for Exploration, Houston Geol. Soc. Houston.

Ginsburg, R. N. 1975: Tidal Deposits: A Casebook of Recent Examples and Fossil Counterparts. Springer Verlag, Berlin. $428 \mathrm{pp}$.

Harland, W. B. 1969: Contribution of Spitsbergen to understanding of tectonic evolution of North Atlantic region. In Kay. M. (Ed.): North Atlantic, geology and continental drift. Am. Ass. Petrol. Geol. Mem. 12, 817-851.

Harland, W. B. 1971: Tectonic transgression in Caledonian Spitsbergen. Geol, Mag. 108, 27-42.

Harland. W. B. 1973: Mesozoic geology of Svalbard. In Pitcher, M. G. (Ed.): Artic Geology. Am. Ass. Petrol. Geol. Mem. 19, 135-148.

Harland. W. B. 1975; Palaeogene correlation in and around Svalbard. Essay Review. Geol. Mag. 112(4), 42!-429.

Harland, W. B., Cutbill, J. L., Friend, P. F.. Gobett, D. J., Holliday, D. W. Maton. P. I.. Parker. J. R. \& Wallis, R. H. 1974: The Billefjorden fault zone, Spitsbergen, the long history of a major tectonic lineament. Nor. Polarinst. Skr. 161. $72 \mathrm{pp}$.

Harland. W. B., Pickton, C. G., Wright, N. R., Croxton, C. A.. Smith. D. G. . Cutbill, J. L. \& Henderson, W. G. 1976: Some coal-bearing strata in Svalbard. Nor. Polarinst. Skr. 164. $89 \mathrm{pp}$.

Harms, J. C. 1975a: Stratification produced by migrating bedforms. Pp. 45-62 in Soc. Econ. Palaeontol. Miner. Short Course No. 2. Dallas
Harms, J. C. 1975b: Stratification and sequence in prograding shoreline deposits. Pp. 103-132 in Soc. Econ. Palaeontol. Miner. Short Course No. 2, Dallas.

Harms, Y. C., Southard, J. B. \& Walker, R. G. 1982: Structures and sequences in clastic rocks. Soc. Econ. Palaeontol. Miner. Short Course No. 9, Calgary.

Hayes, M. O. 1967: Hurricanes as geological agouts: case studies of Hurricanes Carla, 1961, and Cindy, 1963. Rep. Invest. Bur. econ. Geol, Austin, Texas, 61, 54.

Heer, O. 1876: Beiträge zur Fossilen Flora Spitsbergens. $K g l$. Svensk Vit. Akad. Handl. 14(5), 1-141.

Heward, A. P. 1981: A review of wave-dominated clastic shoreline deposits. Earth Sci. Rev. 17, 223-276.

Holliday, D. W. \& Cutbill, J. L. 1972: The Ebbadalen Formation (Carboniferous), Spitsbergen. Proc. Yorks. Geol. Sac. 39, Part 1(1), 1-32.

Howard, J. D., Elders, C. A. \& Heinbokel, J. F, 1975: Animal-sediment relationships in estuarine point bar deposits, Ogeechoe River - Ossabaw Sound, Georgia. Senckenberg. Mar. 7, 181-203.

Hoyt, J. H. \& Weimer, R. J. 1963: Comparison of modern and ancient beaches, central Georgia coast. Am. Ass. Petrol. Geol. Bull. 47, 529-531.

Hunter, R. E., Clifton, H. E. \& Phillips, R. L. 1979: Depositional structures and processes in oblique bar-rip channel systems, southern Oregon coast. J. Sed. Petrol. 49, 711-726.

Irving, E. 1977: Drift of the major continental block since the Devonian. Nature 270, 304-309.

Johnson, H. D. 1978: Shallow siliciclastic seas. Pp. 207-258 in Reading, H. G. (Ed.): Sedimentary Environments and Facies, Blackwell Scientific Publications

Kalgraff, K. 1978. Aspects of Sedimentation in Firkanten Formation, Tertiary, Sualbard. Cand. real. thesis, Geol. Inst. Univ. Bergen. 178 pp.

Kellogg, H. E. 1975: Tertiary stratigraphy and tectonism in Svalbard and continental drift. Am. Ass. Petrol. Geol. Bull. $59,465-485$.

Klein, G. DeV. 1971: A sedimentary model for determining paleotidal range. Geol. Soc. Am. Bull. 82, 2585-2592.

Komar, P. D. 1974: Oscillatory ripple marks and the evaluation of ancient wave conditions and environments. J. Sed. Petrol. 44, 169-180.

Komar, P. D. 1976: Beach Processes and Sedimentation, Prentice Hall, New Jersey. 429 pp.

Komar, P. D. \& Inman, D. L. 1970: Longshore sand transport on beaches. J. Geophys. Res. 75, 5914-5927.

Kumar, N. \& Sanders, J. E. 1976: Characteristics of shoreface storm deposits: Modern and ancient examples. J. Sed. Petrol. 46, 145-162.

Leckie, D. A. \& Walker, R. G. 1982: Storm- and tide-dominated shorelines in Cretaceous moosebar - Lower Gates Interval - outcrop equivalents of deep basin gas trap in Western Canada. Am. Ass. Petrol. Bull. 66, 138-157.

Livshits, Yu. Ya. 1965: Paleogene deposits of Nordenskiöld Land, Vestspitsbergen. Pp. 193-215 in Solokov, N. V. (Ed.): Materialy pool geologii Shpitsbergena. English translation: Boston Spa, Yorkshire, England, National Lending Library Science Technology, 1970.

Livshits, Yu. Ya. 1974: Paleogene deposits and the platform structure of Svalbard. Nor. Polarinst. Skr. 159. $51 \mathrm{pp}$.

Lowell, A. 1972: Spitsbergen Tertiary orogenic belt and the Spitsbergen fracture zone. Geol. Soc. Am. Bull. 83, 30913102.

Major, H. \& Nagy, J. 1972: Geology of the Adventdalen map area. Nor. Polarinst. Skr. $138.58 \mathrm{pp}$. 
Manum, S. \& Throndsen, T. 1978a: Rank of coal and dispersed organic matter and its geological bearing on the Spitsbergen Tertiary. Nor. Polarinst. Arbok 1977, 159-177.

Manum, S. \& Throndsen, T. 1978b. Dispersed organic matter in the Spitsbergen Tertiary. Nor. Polarinst. Arbok 1977, 179-187.

Miller, M. C. \& Komar, P. D. 1980: Oscillation sand ripples generated by laboratory apparatus. J. Sed. Petrol. 50, 173182.

Nathorst, A. G. 1910: Beiträge zur Geologie der Bären-Insel, Spitzbergens und des König-Karl-Landes. Geol. Inst. Univ. Uppsala Bull. 10, 261-416.

Nelson, B. W. 1970: Hydrography, sediment dispersal, and recent historical development of the Po River delta, Italy. In Morgan, J. P. \& Shaver, R. H. (Eds.): Deltaic Sedimentation, Modern and Ancient. Spec. Publ. Soc. Econ. Paleont. Miner., Tulsa, 15, 152-184.

Oomkens, E. 1974: Lithofacies relations in the late Quaternary Niger delta complex. Sedimentology 21, 195-222.

Orvin, A. K. 1934: Geology of the Kings Bay region Spitsbergen. Skr. om Sualbard og Ishavet $57.195 \mathrm{pp}$.

Orvin, A. K. 1940: Outline of the geological history of Spitsbergen. Skr. om Svalbard og Ishavet $78.57 \mathrm{pp}$.

Parker, J. R. 1966: Folding, faulting and dolerite intrusions in the Mesozoic rocks of the fault zone of central Spitsbergen. Nor. Polarinst. Arbok 1964, 47-55,

Raaf, J. F. M. De \& Boersma, J. R. 1971: Tidal deposits and their sedimentary structures. Geol. Mijnb. 50, 479-504.

Ravn, J. P. J. 1922: On the mollusca of the Tertiary of Spitsbergen. Result. Norske Spitsbergeneksped., Skr. om Sualbard og Ishavet 1(2), 1-28.

Reidenouer, D., Williams, E. G. \& Dutcher, R. R. 1979: The relationship between palaeotopography and suphfur distribution in some coals of western Pennsylvania. Pp. 88-101 in Ferm, J. G. \& Horne, J. C. (Eds.): Carboniferous Depositional Environment in the Appalachian Region. Univ. of South Carolina, Columbia.

Reineck, H. E. \& Singh, I. S. 1973: Depositional Sedimentary Environments, Springer Verlag, New York. 439 pp.
Sanders, J. E. \& Kumar, N. 1975: Evidence of shoreface retreat and in-place 'drowning' during Holocene submergence of barriers, shelf off Fire Island, New York. Geol. Soc. Am. Bull. 86, 65-76.

Siedlecka, A. 1970: Investigations of Permian cherts and associated rocks in southern Spitsbergen. Nor. Polarinst. Skr. 147.

Steel, R. J., Dalland, A., Kalgraff, K. \& Larsen, V. 1979: An outline of the history of sedimentation of Svalbards Central Tertiary Basin. Norwegian Sea Symposium, Troms 1979. 29 pp.

Steel, R. J., Dalland, A., Kalgraff, K. \& Larsen, V. 1981: The Central Tertiary Basin of Spitsbergen - Sedimentary development of a sheared-margin basin. Can. Soc. Petrol. Geol. Mem. 7.

Surlyk, F. 1978: Mesozoic geology and palaeogeography of Hochsetter Forland, East Greenland. Geol. Soc. Denmark Bull. 27, 73-87.

Talwani, M. \& Eldholm, O. 1977: The evolution of the Norwegian-Greenland Sea. Geol. Soc. Am. Bull. 88, 967999.

Tønseth, D. 1981: The Sedimentary History of Firkanten Formation (Palaeocene) in the Adventdalen area (Spitsbergen). Cand. real. thesis, Geol. Inst. Univ. Bergen. $181 \mathrm{pp}$.

Vail, P. R., Mitchum, R. M. Jr. \& Thompson, S. 1977: Global cycles of relative changes of sea level. Am. Ass. Petrol. Geol. Mem. 26, 63-97.

Vonderbank, K. 1970: Geologie und Fauna der Tertiaren Ablagenrungen Zentral-Spitsbergens. Nor. Polarinst. Skr. 153. $156 \mathrm{pp}$.

Weimer, R. J. \& Hoyt, J. H. 1964: Burrows of Callianassa major Say, Geologic indicators of littoral and shallow nerittic environments. J. Paleontol. 38, 761-776.

Williams, E. G. \& Keith, M. L. 1979: Relationship between sulphur in coals and the occurrence of marine roof beds. Pp. 88-109 in Ferm, J. C. \& Horne, J. C. (Eds.): Carboniferous Depositional Environments in the Appalachian Region. Univ. of South Carolina, Colombia.

Ytreland, G. K. 1980: Sedimentation along the Western Margin of the Central Tertiary Basin (Firkanten Formation), Spitsbergen. Cand. real. thesis, Geol. Inst. Univ, Bergen. 183 pp. 